\title{
Credit-Investment Activity of Banks of the Ukraine: Financial Globalization, Risks, Stabilization
}

\author{
Natalia V. Trusova ${ }^{1, *}$, Leonid V. Melnyk ${ }^{2}$, Zhanna S. Shilo ${ }^{2}$, Oleksandr S. Prystemskyi ${ }^{3}$ \\ ${ }^{1}$ Department of Finance, Banking and Insurance, Dmytro Motornyi Tavria State Agrotechnological University, Melitopol, 72310 , \\ Ukraine \\ ${ }^{2}$ Department of Finance and Economic Security, National University of Water and Environmental Engineering, Rivne, 33000, Ukraine \\ ${ }^{3}$ Department of Accounting and Taxation, Kherson State Agrarian and Economic University, Kherson, 73006, Ukraine
}

Received March 23, 2021; Revised May 30, 2021; Accepted June 9, 2021

\section{Cite This Paper in the following Citation Styles}

(a): [1] Natalia V. Trusova, Leonid V. Melnyk, Zhanna S. Shilo, Oleksandr S. Prystemskyi, "Credit-Investment Activity of Banks of the Ukraine: Financial Globalization, Risks, Stabilization," Universal Journal of Accounting and Finance, Vol. 9, No. 3, pp. 450 - 468, 2021. DOI: 10.13189/ujaf.2021.090320.

(b): Natalia V. Trusova, Leonid V. Melnyk, Zhanna S. Shilo, Oleksandr S. Prystemskyi (2021). Credit-Investment Activity of Banks of the Ukraine: Financial Globalization, Risks, Stabilization. Universal Journal of Accounting and Finance, 9(3), 450 - 468. DOI: 10.13189/ujaf.2021.090320.

Copyright $\bigcirc 2021$ by authors, all rights reserved. Authors agree that this article remains permanently open access under the terms of the Creative Commons Attribution License 4.0 International License

\begin{abstract}
Today the problem of managing credit and investment risk in the bank in the context of financial globalization remains one of the most relevant problems. At the same time, science may not yet explain the answers to some questions and the banker needs to solve them in practice. Therefore, the construction of a comprehensive system of credit and investment risk management in banks is one of the main components of security effective lending activities of banks. The article considers the features of credit and investment activities of banks in the interbank market in the context of financial globalization. The article reveals that the main economic function of Ukrainian banks in the period of accession to the EU is the credit and investment activity of their clients. State of the loan and investment portfolio and dynamics of loans were analyzed. The model and methods of the integrated stabilizer of credit and investment activity of the bank on the interbank market are developed. The authors proposed a list of methods and actions that unify threats, identify risks and improve the credit and innovation activities of the bank in the period of globalization for countries that are in the process of forming the banking infrastructure.
\end{abstract}

Keywords Loans, Deposits, Banks, Banking System, Credit and Investment Activity, Threats, Risks

\section{Introduction}

The deepening of globalization objectively actualizes the study of the forms of its manifestation in all spheres of socio-economic development, including in the financial sphere. In turn, financial globalization, which is primarily manifested through the liberalization of financial markets and the internationalization of financial services, is making corresponding changes in the banking industry. These trends increase competition in the global financial market and contribute to the convergence of banking practices in many countries, which are accompanied by standardization of national banking systems and intensification of mergers and acquisitions, increasing the number of transnational banks. In terms of scale and consequences, the intensity of competition, the possibility and quality of banking technologies, the underestimation of systemic risks in the context of financial globalization can result in irreparable financial losses for banks.

The liquidity crisis increases the probability of default of individual corporate borrowers and reduces the quality of bank portfolios, which leads to non-repayment of loans.

The main economic function of Ukrainian banks in the accession period to the $\mathrm{EU}$ is the credit and investment activities of their clients, legal entities and individuals, enterprises and farms, etc. The financial condition of the regions of Ukraine served by banks largely depends on how well banks will implement their credit and investment 
functions. Lending and investment activity accounts for about $70 \%$ of the bank's total assets, which provides its income. The issue of credit and investment activities of banks is urgent in ensuring the development of the financial sector. Today the problem of management credit and investment risk in the bank remains one of the most relevant. Experience shows that over time the level of risk will increase. Therefore, the construction of a comprehensive system of credit and investment risk management in banks is one of the main components of ensuring effective lending activities of banks.

These processes objectively require the development of stress indicators to prevent threats to credit and investment activities of banks, focusing on internal financial resources and the potential of Ukrainian banks, sound management decisions and new approaches to regulating the security of the banking system and pre-calculated development scenarios. Theoretical and methodological bases of formation of credit and investment activity of banks in the conditions of financial globalization are reflected in scientific works authored by G. Bekaert [1], B. Hermalin and A. Rose, [2], R. Kiely [3], I. Clark [4], K. Kiljunen [5]. According to conceptual approaches of B. Lasarus [6], L. Pauly and S. Reich [7], E. Perrot [8], R. Robertson and H. Knondker [9], R. Stulz [10]. The development of banks in the context of financial globalization should constantly increase credit and investment activity, and credit relations play a key role in the competence, clarity and balance of staff actions. According to conceptual approaches of E. D. Dolan, K. D. Kempbell and R.D. Kempbell [11], R. Paul Krugman and M. Obstfeld [12], D. Lukianenko [13], S. Onyshko, T. Venhurenko, Yu. Verheliuk and S.B. Manzhos [14], V. Onyshchenko and S. Manzhos [15] the development of banks in the context of financial globalization should constantly increase credit and investment activity, and credit relations play a key role in the competence, clarity and balance of staff actions.

The research of C. Borio and Ph. Lowe [16], C. Borio and M. Drehmann [17], I. Chmutova and V. Biliaieva [18], A. Kondrashykhin [19], V. Kornieiev and S. Kulpinskyi [20] presents methodological approaches to mitigating the threats and risk signals of financial globalization in the field of lending and investing in order to maintain a stable position of banks, substantiating applied developments, taking into account transnationalization and the specifics of the banking system as a whole

Research on problems of possibilities of inclusion of commercial banks in investment Ukrainian economy, which was made by Ukrainian researchers, such as V. Kovalenko [21], O. I. Lavrushin [22], R. Miller and D. Van-Huz Devid [23], Dzh. Sinki [24], Dzh. Sinki, R. Levita and B. Pinsker [25]. Lending and investment activities of banks in the financial globalization world require the development of strategic priorities that enhance the stabilization of the banking sector with the acceleration of credit and investment activity to ensure the sustainable development of banks.
Therefore, the priority of our study is to implement a comprehensive methodological approach to assessing stress indicators of credit and investment activities of banks, which provide adequate protection of depositors and creditors, by unifying the threats of financial globalization and risk identification to determine an integrated stabilizer of the banking system.

\section{Theoretical Overview}

Ukrainian banks still have little experience in lending and investment activities, but the volume of these operations is growing every year. Credit and investment activities of banks involve the formation of credit and investment policy, which represents the formation of a system of targets for credit and investment activities, and the choice of the most effective ways to achieve them. In the organizational aspect, it acts as a set of measures for the organization and management of credit and investment activities, aimed at ensuring the optimal volume and structure of credit and investment assets, increasing their profitability at an acceptable level of risk. The most important interrelated elements of credit and investment policy are strategic and tactical processes of credit and investment management of the bank [26].

The main purpose of the bank's credit and investment policy is to offer the most effective ways to expand the bank's assets from the standpoint of its development prospects and increase its market value. The content of investment management policy can be formulated as follows . Credit and investment policy of the bank is part of the overall financial strategy of the bank, which aimed to select and implement the most effective options and investment instruments to maximize income with limited credit and investment risks [27].

The basis of the organization of credit and investment activities of commercial banks lead the following scientific principles and methods:

- types of portfolios of different investors;

- methods of credit and investment policy implementation;

- graphs of profitability [28, 29].

An important organizational element of credit and investment activities of banks is the formation of loan and investment portfolio, which is a multivariate task that influenced by many factors:

- the type of strategy chosen and the nature of market behavior;

- preferences;

- commitment;

- professional abilities of the investor;

- possession of the conceptual apparatus;

- awareness of the legal framework, skills of marketing research, investment management [30].

A comprehensive analysis on the state of credit and 
investment activities of banks in the real and financial sectors should be carried out in close connection with the overall assessment of the volume and structure of banks' assets, their credit and investment portfolios both in the banking system and in groups of banks and territories depending on the level of their investment attractiveness.

The loan portfolio of Ukrainian banks today has the following structure. Loans to business entities (non-financial corporations sector) for current activities account for $68.4 \%$ of the total loan portfolio; loans to individuals (household sector) $-28.6 \%$; loans to public administration bodies and non-bank financial institutions $-3.0 \%$.

The significantly distorted structure of the credit and investment portfolio of Ukrainian banks (significantly due to the underdevelopment of the stock market) is evidenced by the low share of the securities portfolio in total assets. Small banks do not invest in securities . They are unattractive to almost all types of securities and, above all, government bonds.

\section{Materials and Methods}

The identification of risks and threats of banks' lending and investment activities in the context of financial globalization depends on many factors that make it impossible to generate financial flow of major companies in the economy and increase the quality of service from VIP clients and big business. At the same time, the imperfection of payment systems services for banking services for large businesses and VIP-clients due to poor management of credit and investment activities of the bank leads to a reformatting of front offices to change customer relations, primarily from "client-burden" to client-oriented. The main danger for the bank arises when its internal structure ceases to meet the challenges of financial globalization. In this situation, the bank cannot adapt to the events around it, and the form of organization of credit and investment activities is outdated.

The ability to stabilize the credit and investment activities of the bank through the diagnosis of external and internal threats of financial globalization in the implementation of payment systems for loans and deposits, as well as customer network service, allows assessing the financial security of banks taking into account their target features of the use of modern information technologies, the degree of realization of adaptive potential in the world banking space, the quality of management and monitoring of operational processes and their compliance with the strategic directions of public monetary policy. We have proposed a methodological approach to a comprehensive assessment of stress indicators of credit and investment activities of banks in attracting loans and deposits in the interbank market, by unifying the threats of financial globalization and risk identification to determine the integrated stabilizer of the banking system in servicing depositors and creditors.

When studying the structure of bank liability items, it is necessary to focus on the value of financial resources that increase (decrease) the profitability of banking operations. At the same time, the optimal ratio in the structure of attracted resources is: demand deposits - not more than $30 \%$, time deposits - not less than 50\%, interbank loans - not more than $20 \%$ [31]. Under these conditions, the growth of the value of borrowed resources in the dynamics of the bank's income increases the operating margin, which changes because of resource management policy and the proportional growth of income. However, the sharp rise in interest rates on the bank's deposits should be taken with caution, as there is a possibility of a threat of irrational formation of the resource base in the structure of liabilities and assets.

Dependence of terms of formation of short-term liabilities and assets before placement in bank provides support for its liquidity [32;33]. The decrease in the share of resources "on demand", which are "volatile" liabilities in bank accounts, leads to the absence of the ratio of instantaneous liquid assets, and reduces the profitability of banking operations. Thus, the transformation of these sources into term loans in the near future may lead to the search for resources for their refinancing at the time of demand from depositors. Such sources are funds raised on the interbank market or received from the public at higher rates in order to increase the value of liabilities, but they, consequently, reduce the profitability of banking products. We should note that the growth in the dynamics of "medium-term" and "long-term" liabilities indicates the effectiveness of the bank's lending activities, i.e., the level of stable collateral for the bank's liabilities is determined by formula $(1)[17 ; 18]$ :

$$
\mathrm{K}_{s s}=\frac{\mathrm{A} S_{l}+S_{l_{m}}}{U l_{\mathrm{T}}} \geq 0.75
$$

where: $K_{\text {ст }}-$ the level of stable security of the bank's liabilities; $\mathrm{A} S_{l}$-absolutely stable liabilities; $S_{l_{\mathrm{T}}}-$ stable liabilities; $U l_{\mathrm{T}}-$ unstable liabilities. We consider it expedient to calculate the level of effective use of attracted and borrowed funds by the bank, which characterizes the amount of collateral for liabilities per hryvnia of credit investments. Increasing its value leads to inefficient use of borrowed funds, i.e., the bank attracts and pays more than it places and receives income (formula (2)) [17]:

$$
\mathrm{K}_{\mathrm{e} f}^{a b f}=\frac{L_{b}}{\mathrm{~K}_{c i}+P_{s}} \geq 0.7
$$

where: $K_{e f}^{a b f}-$ the level of effective use of the bank's attracted and borrowed funds; $L_{b}-$ liabilities of the bank; $K_{c i}$ - the amount of credit investments; $P_{s}-$ purchased securities. Attracting loans and deposits on the interbank market requires the bank to determine their total value to balance the structure of credit and deposit accounts subject to the requirements of depositors and creditors (formula (3)) [17]:

$$
I M B_{a}=I M L D+I M L D_{N B}+C a,
$$

where: $I M B_{a}$ - the total amount of borrowed resources in the interbank market; $I M L D$ - volume of loans and deposits attracted on the interbank market; $I M L D_{N B}$-loans and deposits from the NB; $\mathrm{Ca}$ - correspondent accounts. Each 
component of the formula allows identifying special features of credit and investment activities of the bank. If the bank has a significant share of funds attracted to the accounts "LORO" $(\mathrm{Ca})$, the bank should expand the network of correspondent banks, and the speed of payments to its depositors and creditors. That is, the higher the bank's dependence on loans and deposits on the interbank market, the more vulnerable the bank's lending and investment activities, respectively, the risk of losing short-term financial support from other lending banks appears. The degree of dependence $\left(D D_{l d}\right)$ is calculated by formula (4) [17]:

$$
D D_{l d}=\frac{I M L D+I M L D_{N B}}{\text { Obligations }},
$$

where: $D D_{l d}$ - the degree of dependence of the bank on loans and deposits on the interbank market. Determining the ratio of the total amount of interbank resources attracted to the total amount of credit investments of the bank $\left(\mathrm{K}_{1}\right)$ allows adjusting the share of interbank borrowings in credit operations. The growth of this indicator is a sign of imbalance of the bank's liquidity position in the interbank space of credit and investment activities, i.e., there is a threat of reducing the placement of credit resources on bank accounts to meet the needs of customers and depositors, which reduces interbank borrowing (formula (5)) [9]:

$$
\mathrm{K}_{1}=I M B_{a} / T D_{b},
$$

The ratio of borrowed to interbank loans and deposits $\left(\mathrm{K}_{2}\right)$ determines the level of "entry" and "exit" of the bank's resources to the interbank credit market. An increase in the ratio $(>1)$ indicates the inefficiency of the bank's credit and investment activities, i.e. there is a need for the bank in current financing. In this case, the bank is considered a net debtor; if $K_{2}<1$ - the bank is an interbank net lender, which increases its rating and profitability of operations, (formula (6)) [9]:

$$
\mathrm{K}_{2}=I M L D_{a t} / I M L D_{i s} \text {, }
$$

where: $I M L D_{a t}$ - attracted loans and deposits on the interbank market; $I M L D_{i s}-$ loans and deposits issued by the bank to other banking institutions. Within the proposed methodological approach, we consider it appropriate to fill the methodology of comprehensive assessment with a final set of stress indicators that unify threats and identify risks in the credit and investment activities of the bank when attracting loans and deposits in the interbank market in Table 1.Having established the adequacy of indicators (Table 1), the evaluation should bring the results to a single value. To do this, instead of comparing indicators, we use the method of rationing, the essence of which is to reduce the system of various indicators to comparable values in the range from 0 to 1 .

where: $T D_{b}$ - the total debt of the bank.

\begin{tabular}{|c|c|c|c|c|}
\hline \multirow{2}{*}{$\begin{array}{l}\text { Group of } \\
\text { stress indicators }\end{array}$} & \multirow{2}{*}{ Denomination } & \multicolumn{2}{|c|}{ Optimal value } & \multirow{2}{*}{ Practice } \\
\hline & & $\min$ & $\max$ & \\
\hline \multirow{3}{*}{$\begin{array}{l}\text { Capital adequacy } \\
\text { assessment }\end{array}$} & $\begin{array}{l}\text { Level of investment } \\
\text { support }\end{array}$ & 0.15 & 0.85 & $\begin{array}{l}\text { Determines the level of investment funds in the structure of } \\
\text { liabilities }\end{array}$ \\
\hline & $\begin{array}{l}\text { Securing } \\
\text { commitments }\end{array}$ & 0.25 & - & $\begin{array}{l}\text { Indicates the maximum amount of loss for which there are } \\
\text { sufficient investment resources to ensure the reliability of funds } \\
\text { of depositors and other creditors }\end{array}$ \\
\hline & $\begin{array}{l}\text { Use of credit } \\
\text { resources }\end{array}$ & - & 0.8 & $\begin{array}{l}\text { Designed to assess the management of passive operations and } \\
\text { shows the share of borrowed funds aimed at lending }\end{array}$ \\
\hline \multirow{3}{*}{$\begin{array}{l}\text { Assessment of } \\
\text { asset quality }\end{array}$} & $\begin{array}{l}\text { The level of return } \\
\text { on assets }\end{array}$ & - & 0.83 & $\begin{array}{l}\text { Designed to assess the effectiveness of assets. Quantitative } \\
\text { parameters are a preliminary estimate. For a detailed } \\
\text { assessment, it is necessary to allocate loans as part of } \\
\text { income-generating assets, where the conditions of their return, } \\
\text { doubtful and non-standard assets have changed. }\end{array}$ \\
\hline & Risk protection & - & - & $\begin{array}{l}\text { Determines the share of debt in income-generating assets by } \\
\text { which the bank secures liabilities with its profits and reserves } \\
\text { (without using depositors' funds) }\end{array}$ \\
\hline & $\begin{array}{l}\text { The level of } \\
\text { high-risk assets }\end{array}$ & - & - & $\begin{array}{l}\text { Determines the level of risk of the bank's credit policy. } \\
\text { High-risk assets include: securities, overdue debt, excess of } \\
\text { receivables over accounts payable }\end{array}$ \\
\hline \multirow{4}{*}{$\begin{array}{l}\text { Evaluation of } \\
\text { business activity }\end{array}$} & Total credit activity & 0.55 & 0.80 & $\begin{array}{l}\text { Characterizes the liquidity of the bank and the management } \\
\text { system of its assets }\end{array}$ \\
\hline & Investment activity & - & - & $\begin{array}{l}\text { Characterizes the bank's policy in the field of investment in } \\
\text { securities and risk management of credit and investment } \\
\text { activities of the bank }\end{array}$ \\
\hline & Liquidity ratio & - & - & Characterizes the efficiency of credit and investment operations \\
\hline & Refinancing ratio & 1.00 & 1.00 & $\begin{array}{l}\text { Characterizes the level of use of loans and deposits received } \\
\text { from other banks }\end{array}$ \\
\hline
\end{tabular}

Table 1. The system of selected stress indicators for the integrated stabilizer of credit and investment activities of the bank in attracting loans and deposits on interbank market 
The rationing process is statistically determined and clearly defined. Let $\mathrm{x}_{i}, j=\overline{1, m}$ - the initial indicators of stabilization of credit and investment activities of the bank in attracting loans and deposits in the interbank market. To unambiguously compare them, each of the indicators $\mathrm{x}_{i}$ must be normalized, i.e., reduced to the interval $0 \leq \overline{x_{j}} \leq 1$, while $\overline{x_{j}}=1$ corresponds to the optimal (maximum) values of this indicator, and, $\overline{x_{j}}=0$ - unacceptable (minimum) value, respectively, $\overline{\mathrm{x}_{j}}-$ normalized value, which can be considered as its indicator [16].

After the normalization of indicators (formation of a system of stress indicators), the integrated indicator can be calculated as the sum of normalized values using weights. That is, if $x_{i j}$ - the value of any of the $m$ indicators that characterize the stable level of credit and investment activities of the bank in attracting loans and deposits in the interbank market, $j=1, \ldots ; i=1, \ldots, n$, for a certain period of time withnyears, then the integral index will have the form of the following linear function [16]:

$$
I=\sum_{i=1}^{n} \sum_{j=1}^{m} k_{j} \overline{x_{i j}},
$$

where: $k-$ is the weighty factor of the indicator, which determines the degree of influence of the $j$-th stress indicator on the integrated indicator of the $i$-th period; $\overline{x_{i j}}$ - normalized values of indicators $x_{i j}$. The calculated integrated indicator will be1.0 at the optimal (maximum) values of all parameters, which indicates the stabilization of credit and investment activities of the bank to attract loans and deposits in the interbank market. If the obtained indicator is $0-$ it indicates a critical (threatening) state of credit and investment activities of the bank in the interbank market. Standardization of indicators by the method of mathematical statistics is carried out according to the formula (8) [16]:

$$
\overline{x_{i}}=\frac{x_{i}-x_{\min }}{x_{\min } \max , i=\overline{1, n}},
$$

where: $k$ - the amount of selected data (number of indicators) or the number of points in the numerical series. Thus $\overline{x_{i}}=0$ when $x_{i}=x_{\min }$ and $x_{i}=I$, when $x_{i}=$ $x_{\max }$. Rationing of indicators by the method of nonmonotonic dependences is carried out by formula (9) [16]:

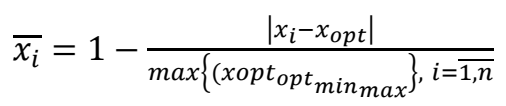

To model the impact of stress indicators on the integrated stabilizer of credit and investment activities of the bank in attracting loans and deposits in the interbank market, we propose using a parametric model of variance-covariance and factor assessment on the basis of covariance. The proposed method for assessing the level of stabilization of credit and investment activities of the bank to attract loans and deposits in the interbank market is presented in Figure 1.

It should be noted that the hierarchy of payment space in the credit and investment activities of banks between the center and the periphery is manifested at all spatial levels to attract loans and deposits. Spatially polarized platform of banking systems in attracting loans and deposits at the macro level ensures the functioning of the payment market for users of banking services through transfers and forms the interaction of banks with depositors and creditors. The center controls cash, financial, and investment flows . It uses new financial technologies and processes, which has more advanced forms of settlement process . It is a "supplier of money", which generates credit and investment potential of the state and provides profitability and liquidity of banks' loan and investment portfolio [34].

Thus, the constant dominance of the center over the periphery ensures the continuity of credit and investment activities of banks in attracting loans and deposits, which are characterized by a significant level of risk in several areas (because they are exposed to payment instruments, delivery systems, communications, clearing and settlement mechanisms, as well as the monetary sector of the economy as a whole) and is explained by the volume and size of operations performed in these systems.

In the context of interbank spatial communication (direct influence of the central bank on the impulses of the banking system to attract loans and deposits for the objects of the settlement process and the subjects of banking services), the formation of the planned level of profitability, the risk and liquidity of banks (payment institutions) within the framework of appropriate principles, methods, levers, cash flows, for the implementation of rapid response and adaptation to external and internal threats of financial globalization are allowed. Defining targets for credit and investment activities of the bank and its interaction with interbank market participants in attracting loans and deposits to serve customers and depositors on the basis of financial instruments allows implementing polarized interbank space on quantitative and qualitative limits of risk minimization and allows carrying out:

1. The analysis of destructive determinants of interbank peripheral risk in attracting loans and deposits, as well as stimulating determinants (formed on financial and technological innovations) of the interbank market center, by determining macro and micro-factors influencing the amount of credit and investment risks in attracting loans and deposits, provide the optimal composition of factors that can reduce the gap with the center of the interbank space (national banking systems) or join the architecture of the global systems of the interbank market;

2. The structural adjustment of the polarized interbank space in attracting loans and deposits by determining the probable deviation from the expected results of bank liabilities, providing cash flow in active-passive operations, stabilizing credit and investment activities of banks in servicing the network of customers and depositors; 
3. modeling clear impulses of consistent organization of financial risk management by building a model of the bank's loan and investment portfolio for loans and deposits in order to achieve optimal risk, profitability and liquidity, increase the density of peripheral interaction with the interbank market - coordinator of loans and deposits.

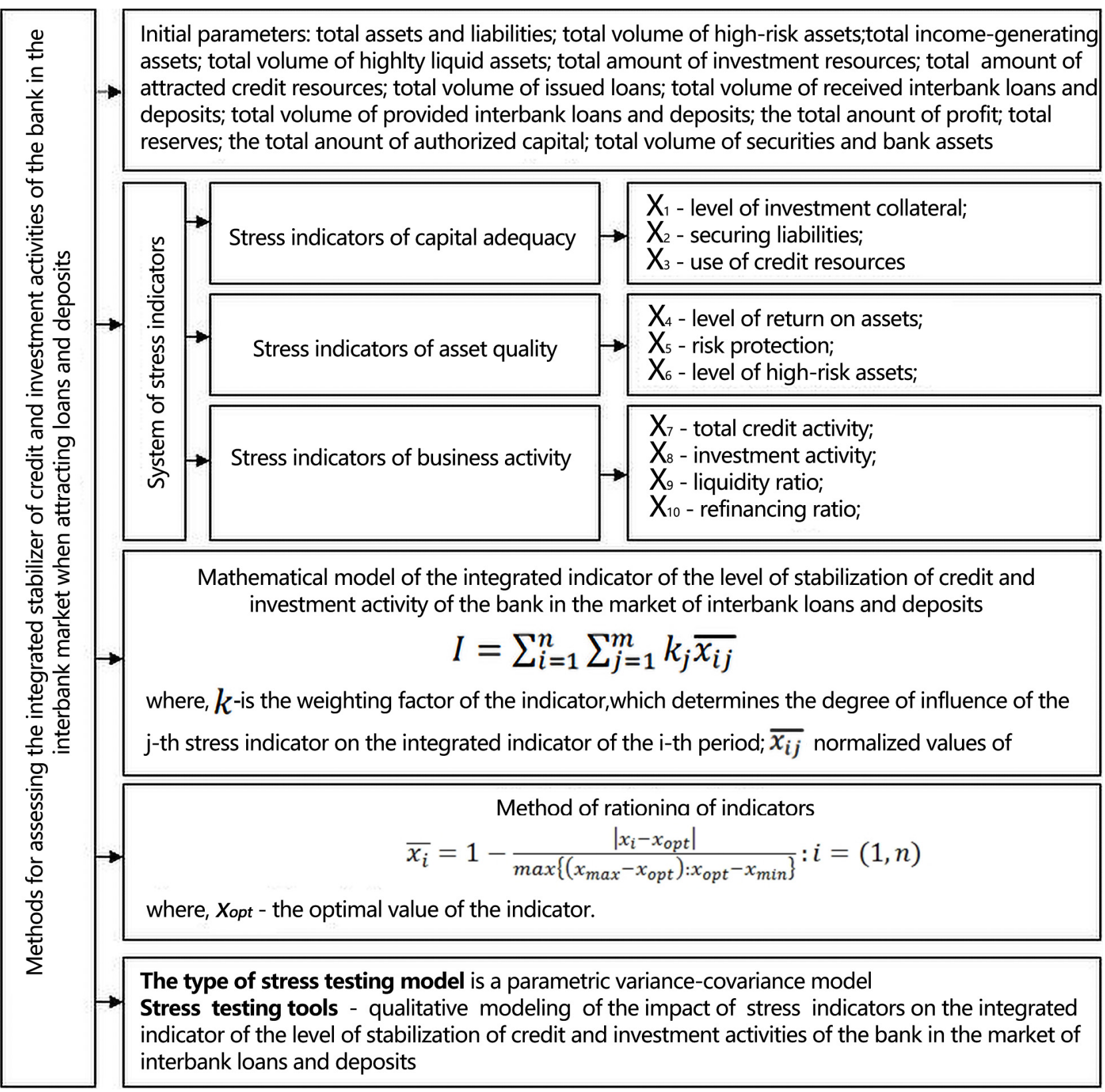

Figure 1. Model of evaluation of the integrated stabilizer of credit and investment activities of the bank on the interbank market in attracting loans and deposits 


\section{Results and Discussion}

Modern processes of market environment development led to a significant increase in competition in domestic and foreign financial markets, which, in turn, leads to the emergence of qualitatively new factors that affect the organization and efficiency of lending and investment activities of banks. This is naturally accompanied by the actualization of the problem of increasing the concentration of banks' efforts to achieve a competitive position in the market with a focus on the following main areas of credit and investment activities: retail banking universal financial products; private clients - asset management; "pure" and classic investment business; wholesale business - risk management, as well as implementation - logistics. Focusing on above-average losses means focusing on those types of credit and investment activities of the bank, which, at least, can provide financial stabilization and prospects for the development of the banking system among a group of competitors.

By the way, M. Flannery notes that the European banking business can be judged by the development strategy of the German banks, according to which the banks clearly define mortgage lending and foreign trade financing as the main areas of its lending and investment activities and continues to penetrate with these products in other countries [35]. Now the investment business, serving VIP clients and depositors, are the most profitable and fast-growing sectors of the product market. We allow a natural transition to another version of universalization, in particular the supplier of integrated financial products.
Such a provider is a financial institution that combines services and products provided by a bank and asset management companies.

At the same time, the process of financial globalization and the formation of the global "banking industry" contribute to the standardization of national banking systems and the emergence of a single, dominant model of credit and investment activities of the bank. Thus, D. Diamond, R. Rajan believes that such a model will be a bank that focuses solely on maximizing shareholder income, or "dividend bank". In the lending and investment activities of banks, priority is given to capturing the most profitable market segments, carefully monitoring costs and profitability of operations, setting extremely accurate product tariffs, transparency of financial statements, finding the optimal size of the bank during the concentration.

Due to the outlined principles, the bank-dividend can reach a high level of return on equity in the future $15-20 \%$ [36]. Increasing the volume of capital and assets for Ukrainian banks is an objective necessity, because C. Borio and M. Drehmann in this regard, "Ukrainian banks in terms of assets are extremely small in terms of international comparisons and one of the long-term trends in banking sector should be the integration and merger of banks" [17]. Experts from the World Bank and the International Monetary Fund are convinced that banks with a capital of less than 50 million Euros [37-39] should not operate in Ukraine. In 2019, only 25 Ukrainian banks with 158 met this criterion $(15.8 \%$ of the total number of banks submitting financial statements to the National Bank of Ukraine (NBU) (Figure 2).

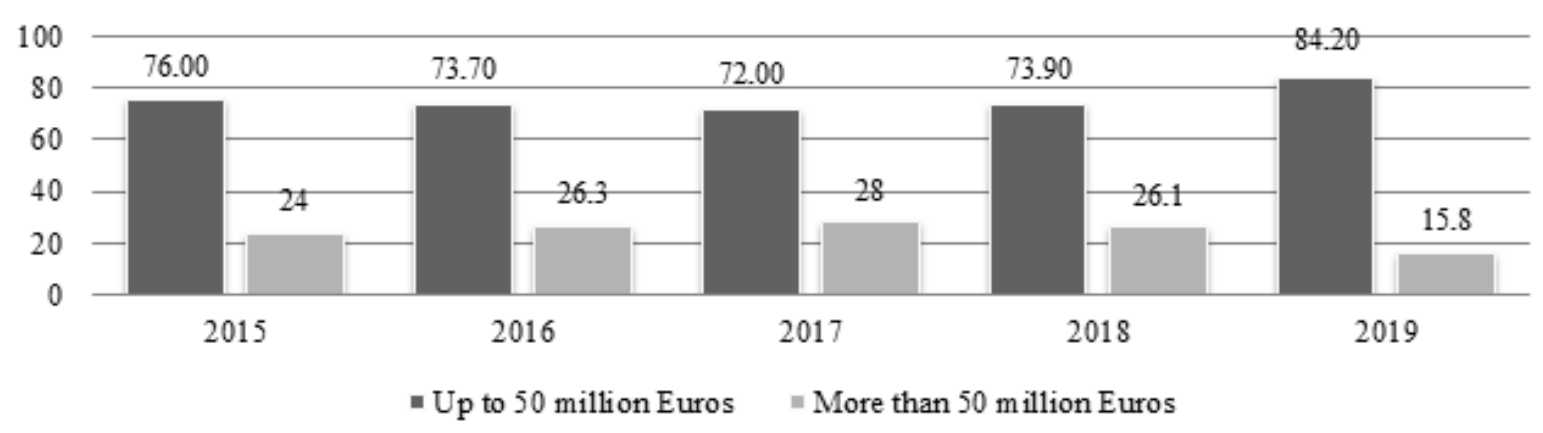

Figure 2. Distribution of the banking sector of Ukraine by the amount of capital for $2015-2019, \%$ [33] 


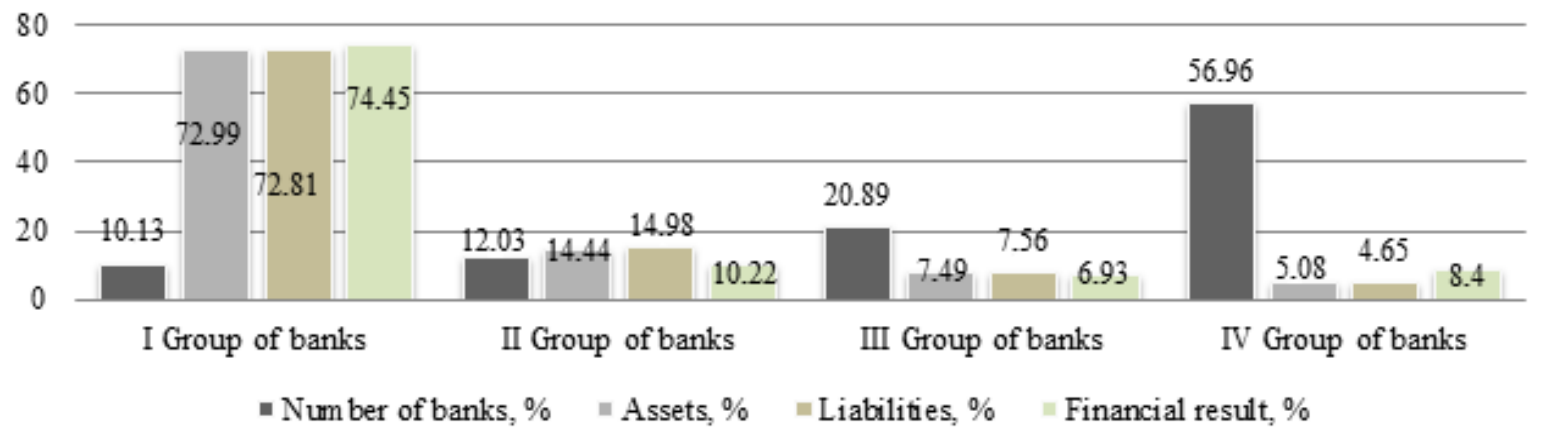

Figure 3. Characteristics of the banking sector of Ukraine by groups on average for 2015-2019, \% [33]

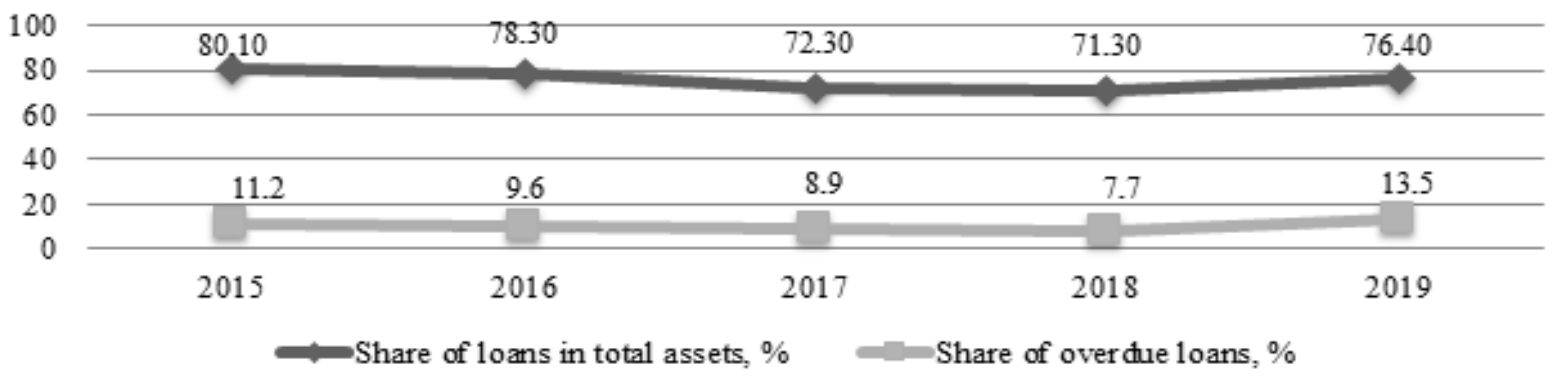

Figure 4. Dynamics of the share of loans in total assets and the share of overdue debt on loans in the loan portfolio of banks of Ukraine in 2015-2019, $\%$ [38]

In 2019, the sixteen largest banks of Ukraine (banks of the first group) owned $72.9 \%$ assets of the entire banking sector (33198.4 million Euros), and the fourth group, which includes 90 banks, accounted for only $5.08 \%$ assets of the banking sector (2307.8 million Euros) (Figure3).

A component of ensuring the financial stability of banks is their profitability. In 2015-2019, the activity of the banking sector was unprofitable: in $2015-0.449$ billion Euros, and in $2016-0.266$ billion Euros. Banks were able to end 2017-2018 with a profit, but in 2019 the loss of the banking sector amounted to 1.83 billion Euros, while the return on assets was $-4.07 \%$, return on capital $-(-30.46 \%)$. The negative financial result of banks was formed by Group I banks that lent to large-scale projects in Ukraine. According to the NBU, the share of negatively classified debt in the total credit debt of banks for 2018-2019 increased from $12.9 \%$ to $19.0 \%$. In particular, overdue loans increased by $92.5 \%$ (by 2.26 billion Euros.) - to 4.69 billion Euros (13.5\% of total loans). Since 2015, there has been a decrease in the share of loans in total assets, which in 2019 was $76.4 \%$, and in $2015-80.1 \%$ (Figure 4).

Indicators of financial stability of the banking system of Ukraine for these groups are given in Table 2. The basic financial indicators in 2019 significantly deteriorated compared to 2015. The $\mathrm{I}_{1}$ index in 2019 was $15.96 \%$, which is 2.3 percentage points lower than in 2018; the $\mathrm{I}_{2}$ index decreased by 2.28 percentage points; the $\mathrm{I}_{11}$ index decreased by 2.36 percentage points. The high volatility of exchange rates in 2019 worsened the base indicator $\mathrm{I}_{12}$, which was $23.67 \%, \quad 16.73$ percentage points higher than in 2018. The quality of banks' assets deteriorated and their profitability decreased: an increase in non-performing loans led to the growth of the base indicator $\mathrm{I}_{4}$ in 2019 by 3.84 percentage points compared to 2018. Receipt of losses by banking institutions in 2019 confirms the minus indicators $\mathrm{I}_{6}(-0.93 \%)$ and $\mathrm{I}_{7}(-7.06 \%)$. This information on the indicators of financial stability is confirmed by data on economic standards of the NBU (Table 3 ).

Thus, according to Table 3, over the last two years (2018-2019) liquidity ratios have decreased: $\mathrm{H}_{4}$ decreased by 12.27 percentage points and $\mathrm{H}_{6}-$ by 1.17 percentage points. In addition, $\mathrm{H}_{2}$ ratio was $15.60 \%$, which is 2.66 percentage points lower compared to 2018. The size of banking risks increased significantly: $\mathrm{H}_{8}$ was 250.04 , which is 77.99 higher compared to 2018. The transition of PJSC "Privatbank" to state ownership has dramatically changed the structure of the entire banking sector , so in 2017 the share of state-owned banks in net assets increased to $51.4 \%$ and to $54.9 \%$ in 2018 . In 2019 the share of state-owned banks in net assets decreased by 0.2 percentage points and amounted to $54.7 \%$. 
Table 2. Indicators of financial stability of the banking system of Ukraine for $2015-2019, \%$ [32; 34; 35$]$

\begin{tabular}{|c|c|c|c|c|c|c|}
\hline & Indicator & 2015 & 2016 & 2017 & 2018 & 2019 \\
\hline \multicolumn{7}{|c|}{ Base indicators } \\
\hline \multirow{3}{*}{$\begin{array}{c}\text { Capital } \\
\text { adequacy }\end{array}$} & Ratio of regulatory capital to risk-weighted assets $\left(\mathrm{I}_{1}\right)$ & 20.83 & 18.9 & 18.06 & 18.26 & 15.96 \\
\hline & Ratio of Level 1 regulatory capital to risk-weighted assets $\left(I_{2}\right)$ & 15.11 & 13.99 & 13.77 & 13.89 & 11.61 \\
\hline & Ratio of non-performing loans minus reserves to equity $\left(\mathrm{I}_{3}\right)$ & 29.17 & 25.76 & 36.03 & 30.65 & 54.98 \\
\hline \multirow{3}{*}{ Asset quality } & Ratio of non-performing loans to total gross loans $\left(\mathrm{I}_{4}\right)$ & 15.27 & 14.73 & 16.54 & 12.89 & 16.73 \\
\hline & Ratio of loans by sectors of the economy to total gross loans $\left(\mathrm{I}_{5}\right)$ & 96.29 & 98.23 & 98.41 & 98.72 & 96.94 \\
\hline & non-residents & 3.71 & 1.77 & 1.59 & 1.28 & 3.06 \\
\hline \multirow{4}{*}{$\begin{array}{l}\text { Profit and } \\
\text { profitability }\end{array}$} & Ratio of net income to average total assets (return on assets) $\left(\mathrm{I}_{6}\right)$ & -1.41 & -0.62 & 0.47 & 0.24 & -0.93 \\
\hline & Ratio of net income to average capital (return on capital) $\left(\mathrm{I}_{7}\right)$ & -9.82 & -4.22 & 3.15 & 1.68 & -7.06 \\
\hline & The ratio of interest margin to gross income $\left(\mathrm{I}_{8}\right)$ & 65.98 & 63.07 & 64.15 & 58.56 & 49.11 \\
\hline & The ratio of non-interest expenses to gross income $\left(\mathrm{I}_{9}\right)$ & 61.89 & 68.26 & 61.45 & 65.95 & 53.45 \\
\hline \multirow{2}{*}{ Liquidity } & Ratio of liquid assets to total assets $\left(\mathrm{I}_{10}\right)$ & 18.84 & 18.65 & 22.15 & 20.63 & 24.31 \\
\hline & Ratio of liquid assets to short-term liabilities $\left(\mathrm{I}_{11}\right)$ & 91.19 & 94.73 & 90.28 & 89.11 & 86.75 \\
\hline $\begin{array}{l}\text { Sensitivity to } \\
\text { market risk }\end{array}$ & Ratio of net open position in foreign currency to capital $\left(\mathrm{I}_{12}\right)$ & 21.61 & 8.41 & 2.50 & 6.94 & 23.67 \\
\hline \multicolumn{7}{|c|}{ Recommended indicators } \\
\hline \multirow{4}{*}{$\begin{array}{c}\text { Capital } \\
\text { adequacy }\end{array}$} & Capital to assets ratio $\left(\mathrm{I}_{13}\right)$ & 14.63 & 14.76 & 15.03 & 15.06 & 12.68 \\
\hline & Ratio of large risks to capital $\left(\mathrm{I}_{14}\right)$ & 161.21 & 164.46 & 172.91 & 172.05 & 246.46 \\
\hline & $\begin{array}{l}\text { Ratio of gross position on financial derivatives from assets to equity } \\
\qquad\left(\mathrm{I}_{16}\right)\end{array}$ & 0.33 & 1.13 & 1.25 & 1.30 & 2.54 \\
\hline & $\begin{array}{l}\text { Ratio of gross position on financial derivatives from liabilities to } \\
\text { equity }\left(\mathrm{I}_{17}\right)\end{array}$ & 0.04 & 0.10 & 0.09 & 0.13 & 0.40 \\
\hline \multirow{4}{*}{$\begin{array}{l}\text { Profit and } \\
\text { profitability }\end{array}$} & Ratio of gains (losses) on financial instruments to gross income $\left(\mathrm{I}_{18}\right)$ & 3.22 & 5.12 & 3.71 & 3.83 & 16.27 \\
\hline & Ratio of staff costs to non-interest costs $\left(\mathrm{I}_{19}\right)$ & 40.73 & 38.91 & 41.32 & 41.04 & 38.71 \\
\hline & Spread between base rates on loans and deposits $\left(\mathrm{I}_{20}\right)$ & 721 & 567 & 485 & 383 & 572 \\
\hline & Spread between highest and lowest interbank rates $\left(\mathrm{I}_{21}\right)$ & 1790 & 2900 & 4494 & 6490 & 2669 \\
\hline Liquidity & $\begin{array}{l}\text { Ratio of customer deposits to total gross loans (excluding interbank } \\
\qquad \text { loans) }\left(\mathrm{I}_{22}\right)\end{array}$ & 56.01 & 61.19 & 69.80 & 73.34 & 66.25 \\
\hline \multirow{2}{*}{$\begin{array}{c}\text { Sensitivity } \\
\text { to market risk }\end{array}$} & Ratio of foreign currency loans to total gross loans $\left(\mathrm{I}_{23}\right)$ & 48.23 & 42.13 & 37.66 & 34.72 & 45.91 \\
\hline & Ratio of foreign currency liabilities to total liabilities $\left(\mathrm{I}_{24}\right)$ & 51.25 & 49.76 & 49.22 & 43.25 & 45.68 \\
\hline
\end{tabular}

Table 3. The value of economic standards of the banking system of Ukraine for 2015-2019 [36]

\begin{tabular}{|c|c|c|c|c|c|}
\hline Standard & 2015 & 2016 & 2017 & 2018 & 2019 \\
\hline Minimum regulatory capital normative (million Euros), $\mathrm{H}_{1}$ & 5557.7 & 6164.2 & 6179.9 & 7080.3 & 6526.7 \\
\hline Regulatory capital adequacy ratio (not less than $10 \%$ ), $\mathrm{H}_{2}$ & 20.83 & 18.9 & 18.06 & 18.26 & 15.60 \\
\hline $\begin{array}{l}\text { Normative of the ratio of regulatory capital to total assets } \\
\text { (not less than } 9 \%), \mathrm{H}_{3}\end{array}$ & 14.57 & 14.96 & 14.89 & 13.98 & - \\
\hline Instant liquidity normative (not less than $20 \%$ ), $\mathrm{H}_{4}$ & 58.80 & 58.48 & 69.26 & 56.99 & 57.13 \\
\hline Current liquidity normative (not less than $40 \%$ ), $\mathrm{H}_{5}$ & 77.33 & 70.53 & 79.09 & 80.86 & 79.91 \\
\hline Short-term liquidity normative (not less than $20 \%$ ), $\mathrm{H}_{6}$ & 91.19 & 94.73 & 90.28 & 89.11 & 86.14 \\
\hline Normative of the maximum size of credit, $\mathrm{H}_{7}$ & 21.04 & 20.76 & 22.10 & 22.33 & 22.01 \\
\hline $\begin{array}{c}\text { Normative of large banking risks (not more than } 8 \text { times the size } \\
\text { of regulatory capital), } \mathrm{H}_{8}\end{array}$ & 161.20 & 164.46 & 172.91 & 172.05 & 250.04 \\
\hline Normative of the maximum size of credits, guarantees, $\mathrm{H}_{9}$ & 0.81 & 0.57 & 0.37 & 0.36 & 0.13 \\
\hline $\begin{array}{l}\text { Normative of the maximum total size of credits, the guarantees given to insiders (no } \\
\text { more than } 30 \%), \mathrm{H}_{10}\end{array}$ & 2.25 & 2.51 & 2.41 & 1.63 & 1.37 \\
\hline $\begin{array}{l}\text { Normative for investing in securities separately for each institution (not more than } \\
\qquad 15 \%), \mathrm{H}_{11}\end{array}$ & 0.05 & 0.06 & 0.09 & 0.04 & 0.01 \\
\hline Normative of the total amount of investment (not more than $60 \%$ ), $\mathrm{H}_{12}$ & 3.35 & 3.24 & 3.48 & 3.15 & 2.97 \\
\hline
\end{tabular}


The share of the public sector of the banking system in the volume of retail deposits with the nationalization of PJSC "Privatbank" increased, compared to 2015, to almost three times to $62.5 \%$ in 2018 , and in 2019 to $63.4 \%$ (Figure 5).

During 2015-2019, there is a general trend towards an increase in total gross loans from 35.51 billion Euros up to 38.55 billion Euros, i.e., on $8.6 \%$. There was also a decrease in the volume of lending in the national currency - by 2.35 billion Euros (by 12.9\%), while the volume of gross lending to businesses increased by 3.42 billion Euros, individuals - on the contrary decreased by 0.38 billion Euros. The increase in foreign currency lending amounted to 0.69 billion Euros (4.0\%), in particular, the volume of lending to businesses increased by 2.07 billion Euros $(15.0 \%)$, and the volume of loans granted to individuals decreased by 1.38billion Euros, which amounted to $39.6 \%$ (Figure 6). Deposits of business entities and individuals traditionally dominate in the structure of liabilities of banking institutions. Thus, the share of funds of business entities increased from $25.0 \%$ in 2015 to $35.7 \%$ in 2019 , and the share of funds of individuals - from $35.6 \%$ to $42.2 \%$ respectively. In general, the share of funds of individuals and business entities in the liabilities of banking structures increased during the study period from $60.6 \%$ to $77.9 \%$ (Figure 7 ).

To test the proposed methodological approach to a comprehensive assessment of credit and investment activities of banks in attracting loans and deposits in the interbank market, we calculated stress indicators that take into account the threats of financial globalization and identify risks to determine the integrated stabilizer of the banking system.

Banks of Ukraine that carried out their credit and investment activities during 2017-2019 were selected. According to the data of public financial reporting, the initial data necessary for the calculation of the specified stress indicators were formed (according to Table 1, Figure 1). In Table 4 calculations of the first five banks from the selected population are presented. The normative values of coefficients for the integrated stabilizer of credit and investment activity of banks on the interbank market when attracting loans and deposits are calculated (Table 5).

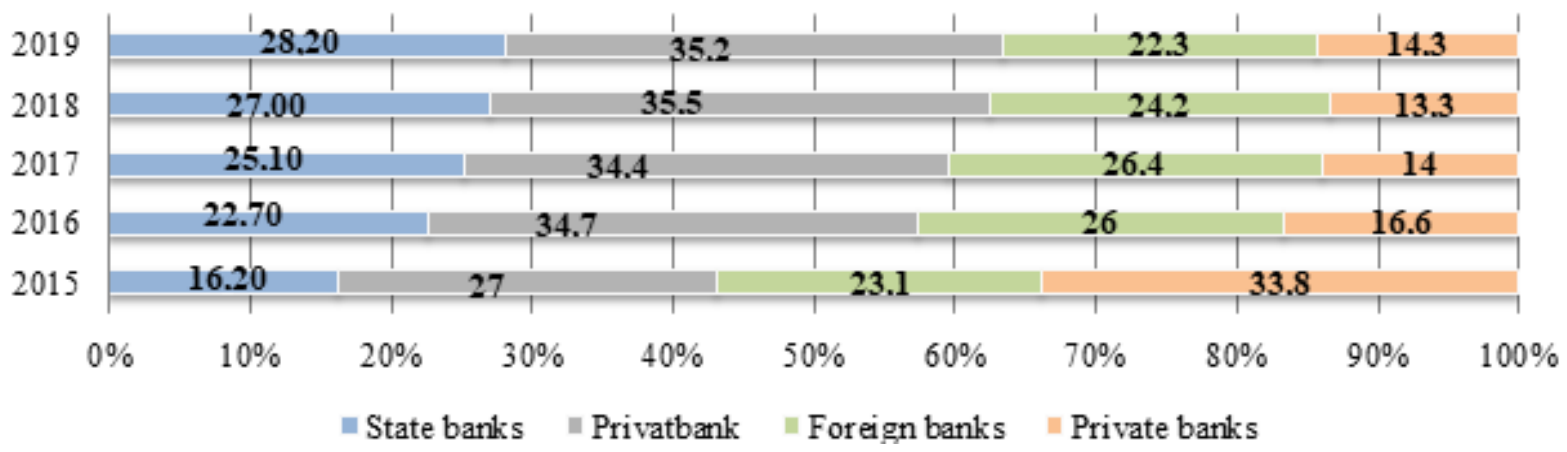

Figure 5. Dynamics of distribution of deposits of individuals by groups of banks in Ukraine, in 2015-2019, \%

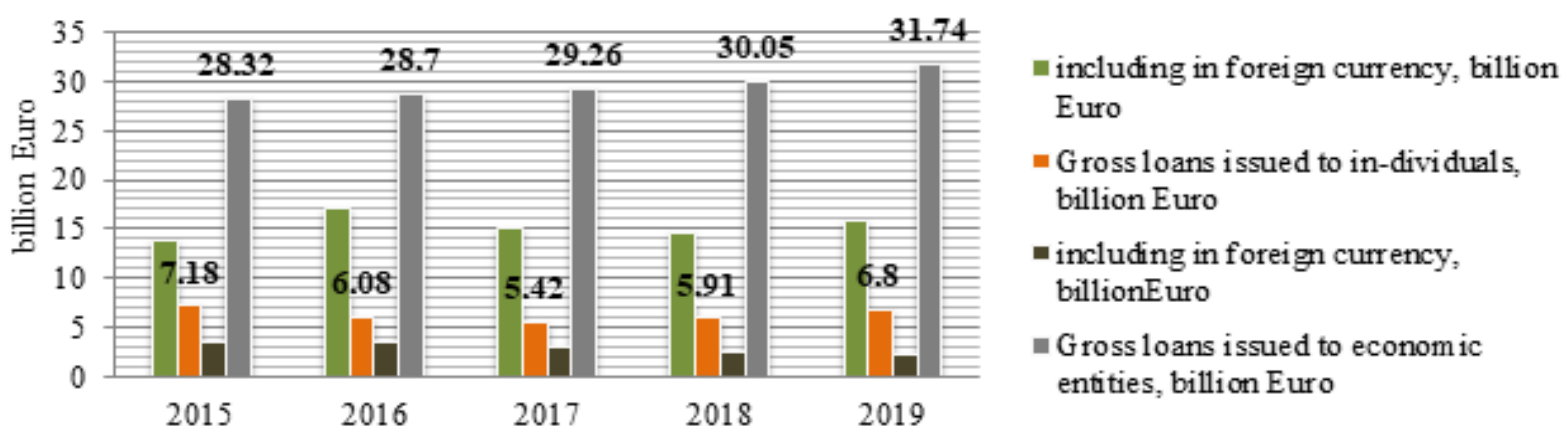

Figure 6. Dynamics of change in the volume of gross loans of Ukrainian banks in 2015-2019, billion Euros 


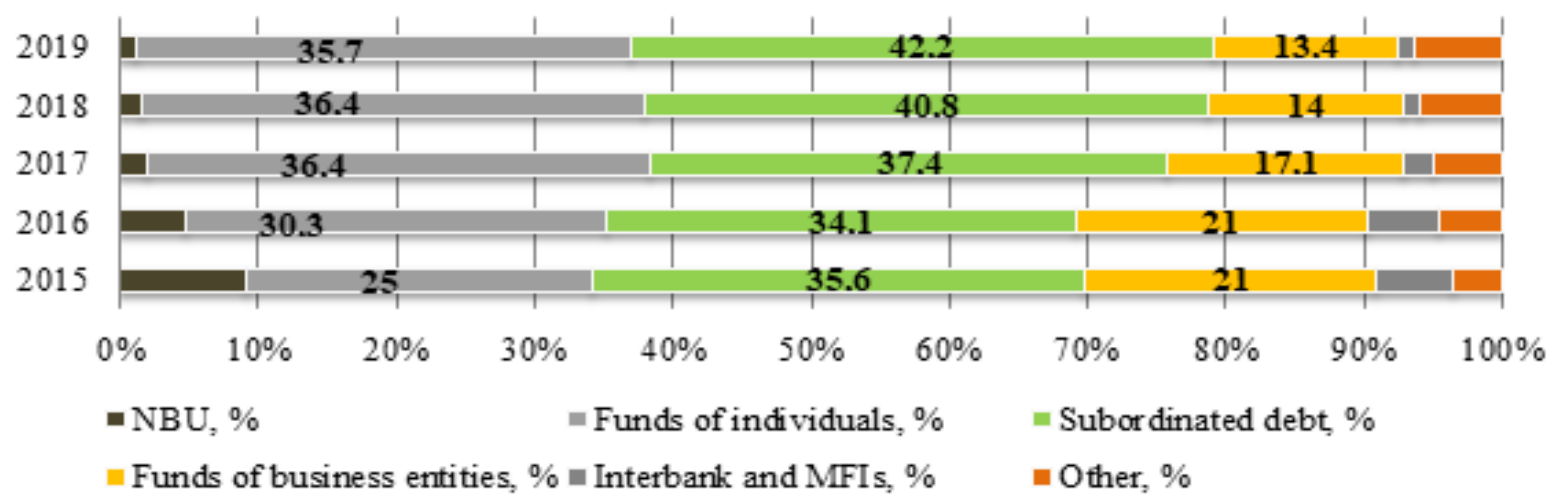

Figure 7. Dynamics of the architecture of liabilities of Ukrainian banks by group of creditors, $2015-2019, \%$

Table 4. Stress indicators of the integrated stabilizer of credit and investment activities of Ukrainian banks in the interbank market when attracting loans and deposits

\begin{tabular}{|c|c|c|c|c|c|c|}
\hline Stress indicators & Years & Bank1 & Bank 2 & Bank 3 & Bank 4 & Bank 5 \\
\hline \multirow{3}{*}{ Level of investment collateral } & 2017 & 0.215131 & 0.148432 & 0.963790 & 0.143335 & 0.157459 \\
\hline & 2018 & 0.190584 & 0.182226 & 0.933052 & 0.095648 & 0.258866 \\
\hline & 2019 & 0.322674 & 0.244982 & 0.954392 & 0.061934 & 0.181512 \\
\hline \multirow{3}{*}{ Securing liabilities } & 2017 & 0.274098 & 0.174305 & 26.62332 & 0.167317 & 0.186885 \\
\hline & 2018 & 0.235458 & 0.222832 & 13.93692 & 0.105764 & 0.349283 \\
\hline & 2019 & 69.2499 & 52.53188 & 135.9919 & 12.82633 & 32.20078 \\
\hline \multirow{3}{*}{ Use of credit resources } & 2017 & 0.629337 & 0.67916 & 5.95932 & 0.806074 & 0.38096 \\
\hline & 2018 & 0.556356 & 0.882635 & 2.865144 & 0.771728 & 0.812226 \\
\hline & 2019 & 151.812 & 178.9699 & 32.14385 & 134.2554 & 85.82955 \\
\hline \multirow{3}{*}{ Level of return on assets } & 2017 & 0.496622 & 0.57898 & 0.218282 & 0.691547 & 0.322914 \\
\hline & 2018 & 0.46109 & 0.722088 & 0.192618 & 0.698866 & 0.603373 \\
\hline & 2019 & 0.723533 & 0.862421 & 0.225912 & 0.649259 & 0.486157 \\
\hline \multirow{3}{*}{ Risk protection } & 2017 & 0.035857 & 0.012484 & 0.10211 & 0.019173 & 0.025008 \\
\hline & 2018 & 0.036953 & 0.015155 & 0.288207 & -0.01763 & 0.009424 \\
\hline & 2019 & 0.041866 & 0.006665 & -0.28176 & -0.08287 & -0.24353 \\
\hline \multirow{3}{*}{ Level of high-risk assets } & 2017 & 0.138821 & 0 & 0 & 0 & 0 \\
\hline & 2018 & 0.134901 & 0 & 0 & 0 & 0 \\
\hline & 2019 & 0.016694 & 0.055033 & 3.246117 & 0.158673 & 0.439365 \\
\hline \multirow{3}{*}{ Total credit activity } & 2017 & 0.493947 & 0.578351 & 0.215735 & 0.690536 & 0.320974 \\
\hline & 2018 & 0.450323 & 0.721796 & 0.191816 & 0.697914 & 0.601968 \\
\hline & 2019 & 0.707377 & 0.834625 & 0.225586 & 0.64827 & 0.483811 \\
\hline \multirow{3}{*}{ Investment activity } & 2017 & 0.069039 & 0.05878 & 0.732951 & 0.033829 & 0 \\
\hline & 2018 & 0.062288 & 0.069583 & 0.771231 & 0.024854 & 0 \\
\hline & 2019 & 0.012078 & 0.047462 & 0.733336 & 0.10302 & 0.213601 \\
\hline \multirow{3}{*}{ Liquidity ratio } & 2017 & 0.223474 & 0.345368 & 0.00377 & 0.248995 & 0.089738 \\
\hline & 2018 & 0.198752 & 0.168521 & 0.005915 & 0.201343 & 0.328893 \\
\hline & 2019 & 0.05653 & 0.07908 & 0.164448 & 0.197235 & 0.269765 \\
\hline \multirow{3}{*}{ Refinancing ratio } & 2017 & 0 & 0.063084 & 0 & 0.060977 & 0.052923 \\
\hline & 2018 & 0 & 0 & 0 & 0.00949 & 0 \\
\hline & 2019 & 0.50888 & 0 & 0 & 1.483634 & 0 \\
\hline
\end{tabular}


Table 5. Normative coefficients of the integrated stabilizer of credit and investment activity of banks of Ukraine on the interbank market when attracting loans and deposits

\begin{tabular}{|c|c|c|c|c|c|c|}
\hline Stress indicators & Years & Bank1 & Bank 2 & Bank 3 & Bank 4 & Bank 5 \\
\hline \multirow{3}{*}{ Level of investment collateral } & 2017 & 0.1664 & 0.0956 & 0.9616 & 0.0901 & 0.1052 \\
\hline & 2018 & 0.1542 & 0.1454 & 0.9309 & 0.0549 & 0.2256 \\
\hline & 2019 & 0.4772 & 0.4171 & 0.9656 & 0.2756 & 0.3681 \\
\hline \multirow{3}{*}{ Securing liabilities } & 2017 & 0.0000 & 0.0000 & 0.0000 & 0.0000 & 0.0000 \\
\hline & 2018 & 0.0002 & 0.0002 & 0.0128 & 0.0001 & 0.0003 \\
\hline & 2019 & 0.0445 & 0.0401 & 0.0622 & 0.0295 & 0.0346 \\
\hline \multirow{3}{*}{ Use of credit resources } & 2017 & 0.1023 & 0.1104 & 0.9683 & 0.1310 & 0.0619 \\
\hline & 2018 & 0.1077 & 0.1709 & 0.5546 & 0.1494 & 0.1572 \\
\hline & 2019 & 0.0098 & 0.0115 & 0.0021 & 0.0086 & 0.0055 \\
\hline \multirow{3}{*}{ Level of return on assets } & 2017 & 0.5438 & 0.6341 & 0.2388 & 0.7574 & 0.3534 \\
\hline & 2018 & 0.4650 & 0.7283 & 0.1942 & 0.7049 & 0.6086 \\
\hline & 2019 & 0.7500 & 0.8940 & 0.2340 & 0.6730 & 0.5039 \\
\hline \multirow{3}{*}{ Risk protection } & 2017 & 0.8166 & 0.8145 & 0.8225 & 0.8151 & 0.8157 \\
\hline & 2018 & 0.0025 & 0.0023 & 0.0047 & 0.0021 & 0.0023 \\
\hline & 2019 & 0.0254 & 0.0253 & 0.0243 & 0.0250 & 0.0244 \\
\hline \multirow{3}{*}{ Level of high-risk assets } & 2017 & 0.1396 & 0.0000 & 0.0000 & 0.0000 & 0.0000 \\
\hline & 2018 & 0.0998 & 0.0000 & 0.0000 & 0.0000 & 0.0000 \\
\hline & 2019 & 0.0001 & 0.0002 & 0.0112 & 0.0005 & 0.0015 \\
\hline \multirow{3}{*}{ Total credit activity } & 2017 & 0.5417 & 0.6343 & 0.2366 & 0.7573 & 0.3520 \\
\hline & 2018 & 0.4544 & 0.7283 & 0.1935 & 0.7042 & 0.6074 \\
\hline & 2019 & 0.7346 & 0.8668 & 0.2343 & 0.6733 & 0.5025 \\
\hline \multirow{3}{*}{ Investment activity } & 2017 & 0.0942 & 0.0802 & 1.0000 & 0.0462 & 0.0000 \\
\hline & 2018 & 0.0808 & 0.0902 & 1.0000 & 0.0322 & 0.0000 \\
\hline & 2019 & 0.0165 & 0.0647 & 1.0000 & 0.1405 & $0, .913$ \\
\hline \multirow{3}{*}{ Liquidity ratio } & 2017 & 0.2375 & 0.3693 & 0.0000 & 0.2651 & 0.0929 \\
\hline & 2018 & 0.2111 & 0.1788 & 0.0049 & $0, .139$ & 0.3503 \\
\hline & 2019 & 0.0503 & 0.0741 & 0.0079 & 0.1989 & 0.2756 \\
\hline \multirow{3}{*}{ Refinancing ratio } & 2017 & 0.0000 & 0.0194 & 0.0000 & 0.0187 & 0.0162 \\
\hline & 2018 & 0.0000 & 0.0000 & 0.0000 & $0, .176$ & 0.0000 \\
\hline & 2019 & 0.0583 & 0.0000 & 0.0000 & 0.1700 & 0.0000 \\
\hline
\end{tabular}

Table 6. Weighting coefficients of the integrated stabilizer of credit and investment activity of banks of Ukraine on the interbank market when attracting loans and deposits

\begin{tabular}{|c|c|c|c|}
\hline $\begin{array}{l}\text { Group of } \\
\text { stress } \\
\text { indicators }\end{array}$ & $\begin{array}{l}\text { Weight } \\
\text { factor by } \\
\text { group }\end{array}$ & Name of indicator & $\begin{array}{l}\text { Weight of } \\
\text { individual } \\
\text { indicators }\end{array}$ \\
\hline \multirow{3}{*}{$\begin{array}{c}\text { Assessment } \\
\text { of capital } \\
\text { adequacy }\end{array}$} & \multirow{3}{*}{0.4} & $\begin{array}{c}\text { Level of investment } \\
\text { collateral }\end{array}$ & \multirow{3}{*}{0.133} \\
\hline & & Securing liabilities & \\
\hline & & $\begin{array}{l}\text { Use of credit } \\
\text { resources }\end{array}$ & \\
\hline \multirow{3}{*}{$\begin{array}{c}\text { Assessment } \\
\text { of asset } \\
\text { quality }\end{array}$} & \multirow{3}{*}{0.3} & $\begin{array}{l}\text { Level of return on } \\
\text { assets }\end{array}$ & \multirow{3}{*}{0.100} \\
\hline & & Risk protection & \\
\hline & & $\begin{array}{l}\text { Level of high-risk } \\
\text { assets }\end{array}$ & \\
\hline \multirow{4}{*}{$\begin{array}{l}\text { Assessment } \\
\text { of business } \\
\text { activity }\end{array}$} & \multirow{4}{*}{0.3} & Total credit activity & \multirow{4}{*}{0.060} \\
\hline & & Investment activity & \\
\hline & & Liquidity ratio & \\
\hline & & Refinancing ratio & \\
\hline
\end{tabular}

Taking into account the norms of the Instruction on the procedure for regulating the activities of banks in Ukraine and the International Convergence on Measurement and Capital Requirements (Basel III), which determine the priority of calculated standards, taking into account regulations and division of coefficients into blocks on economic essence, significant coefficients of the correspondent account are determined (Table 6).

Based on the established weights, the forecast of the integrated stabilizer of credit and investment activities of Ukrainian banks in the interbank market with loans and deposits for the aggregate sample of banks (29 banks of Ukraine) in descending order, for the period 2020-2022 (Table 7).

The modeling of the influence of stress indicators on the integrated stabilizer of credit and investment activity of Ukrainian banks on the interbank market in attracting loans and deposits, using parametric matrices of variance-covariance is carried out. The chain impact of external and internal threats of financial globalization on the 
integrated indicator in the model calculation of matrices of correlations $\left(C_{i j}\right)_{k}$ for each stress indicator of credit and investment activities of banks in the interbank market when attracting loans and deposits, where: $k$ - the studied indicator is evaluated. In the matrices at the intersection of $i$ and $j$ is the coefficient of cross-correlation between the numerical series of the stress indicator of the integrated stabilizer for the bank $i$ and the numerical series of the stress indicator of the integrated stabilizer for the bank $j$. To visualize the matrices of mutual correlation of the impact of the studied indicators "color maps" that were built, the values of correlation coefficients are given in color - the color is close to dark red when approximating the value of the correlation coefficient to +1.0 ; and to dark blue when the correlation coefficient value approaches -0.1 . The results of the above matrices of correlation for the most influential stress indicators on the integrated stabilizer of credit and investment activities of banks in the interbank market (hedging, total lending activity, level of return on assets, refinancing ratio, level of high-risk assets, liquidity ratio, investment activity, use of credit resources, collateral) are shown in Figure 8-17.

Table 7. Forecast of the integrated stabilizer of credit and investment activity of banks of Ukraine on the interbank market when attracting loans and deposits for 2020-2022

\begin{tabular}{|c|c|c|c|}
\hline \multirow{2}{*}{ Name of the bank } & \multicolumn{3}{|c|}{$\begin{array}{l}\text { Integrated stabilizer of credit and investment activity of banks on the } \\
\text { interbank market }\end{array}$} \\
\hline & 2020 & 2021 & 2022 \\
\hline PRIVATBANK & 0.249619756 & 0.219661113 & 0.327589375 \\
\hline IDEA BANK & 0.196806764 & 0.303215042 & 0.312477686 \\
\hline RVS BANK & 0.324917894 & 0.305458747 & 0.298524495 \\
\hline BANK OF INVESTMENTS AND SAVINGS & 0.246854083 & 0.178138644 & 0.291222218 \\
\hline BANK PORTAL & 0.366674202 & 0.319463794 & 0.288791594 \\
\hline CREDOBANK & 0.292598774 & 0.237404681 & 0.282003757 \\
\hline BANK CREDIT DNIPRO & 0.235548670 & 0.168411372 & 0.276339162 \\
\hline RAIFFEISEN BANK AVAL & 0.310986914 & 0.169943172 & 0.263353881 \\
\hline ALPARI BANK & 0.397366982 & 0.268503500 & 0.258536025 \\
\hline KCG BANK & 0.352425346 & 0.239381761 & 0.257846245 \\
\hline BANK ALLIANCE & 0.321215010 & 0.235724886 & 0.245861161 \\
\hline CREDIT OPTIMA BANK & 0.239936315 & 0.196639698 & 0.242447867 \\
\hline ACCORDBANK & 0.259677784 & 0.182524626 & 0.236848812 \\
\hline EURORPOMBANK & 0.275427269 & 0.203322729 & 0.236818183 \\
\hline INDUSTRIAL BANK & 0.261475486 & 0.181015704 & 0.219239686 \\
\hline BANK FORWARD & 0.287222617 & 0.200535971 & 0.217353530 \\
\hline FIRST INVESTMENT BANK & 0.274850702 & 0.180185915 & 0.212855947 \\
\hline TASCOMBANK & 0.325171782 & 0.172122299 & 0.206213428 \\
\hline UNIVERSAL BANK & 0.290983461 & 0.194095372 & 0.206522982 \\
\hline PUMB & 0.25773816 & 0.180209429 & 0.205251395 \\
\hline CREDIT EUROPE BANK & 0.257331331 & 0.150467414 & 0.202347967 \\
\hline OTP BANK & 0.282654437 & 0.188121472 & 0.201679623 \\
\hline PRAVEX-BANK & 0.25019535 & 0.158156929 & 0.194872995 \\
\hline CREDITWEST BANK & 0.265720722 & 0.165136401 & 0.193620116 \\
\hline METABANK & 0.272691908 & 0.171279168 & 0.183825326 \\
\hline UKRSIBBANK & 0.265684952 & 0.149872509 & 0.179043600 \\
\hline NTERNATIONAL INVESTMENT BANK & 0.259639348 & 0.139882970 & 0.172895825 \\
\hline CITYBANK & 0.274379682 & 0.130348513 & 0.163632552 \\
\hline PROMINVEST & 0.285576554 & 0.177258331 & 0.158688627 \\
\hline
\end{tabular}




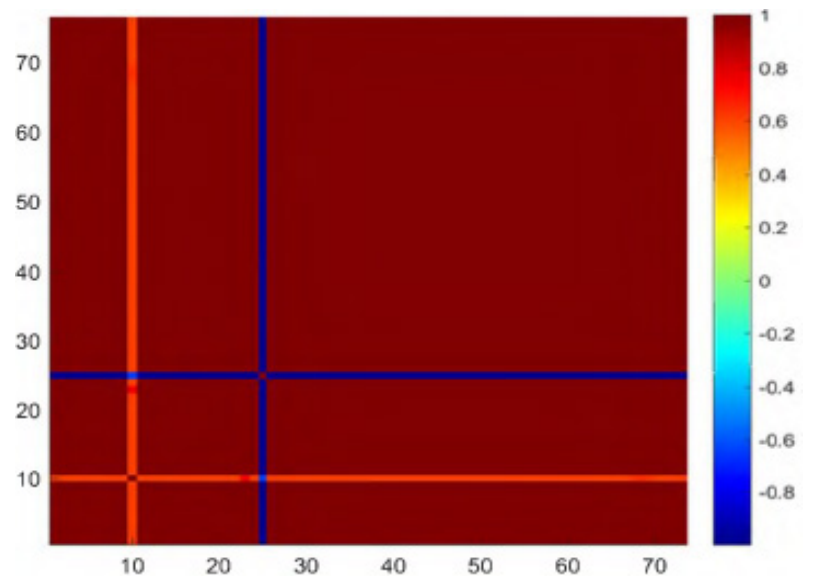

Figure 8. Matrix of mutual correlation of the impact of the stress indicator "Risk protection" on the integrated stabilizer of credit and investment activities of banks in attracting loans and deposits

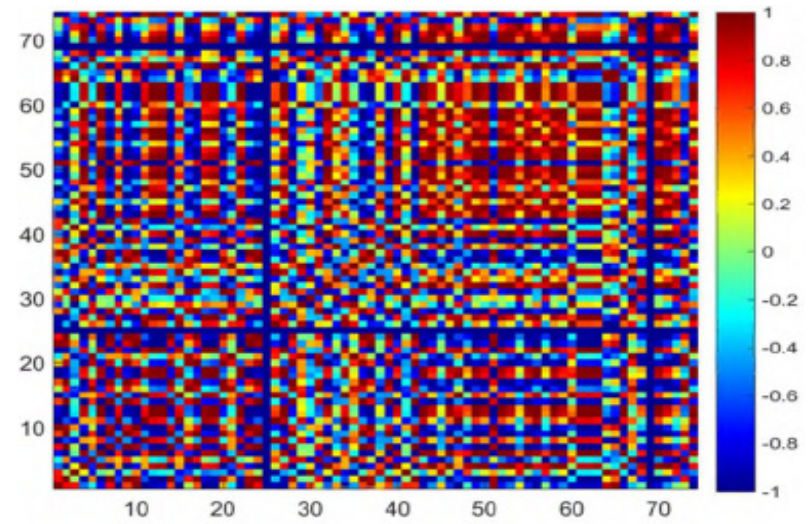

Figure 9. Matrix of mutual correlation of the impact of the stress indicator "Total lending activity" on the integrated stabilizer of credit and investment activities of banks in attracting loans and deposits

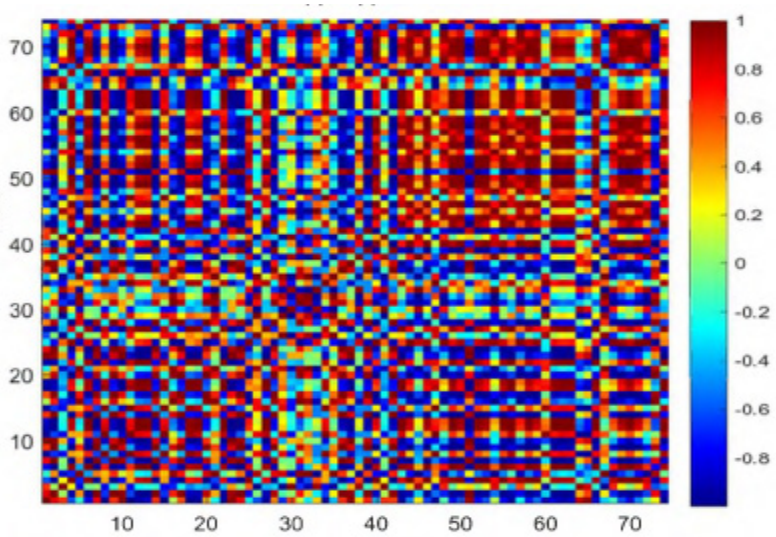

Figure 10. Matrix of mutual correlation of the impact of the stress indicator "Level return on assets" on the integrated stabilizer of credit and investment activities of banks in attracting loans and deposits

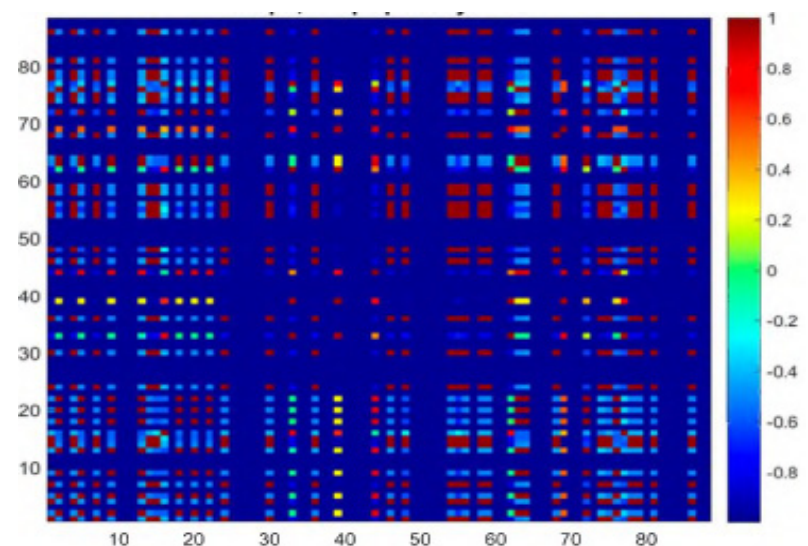

Figure 11. Matrix of mutual correlation of the impact of the stress indicator "Refinancing ratio" on the integrated stabilizer of credit and investment activities of banks in attracting loans and deposits

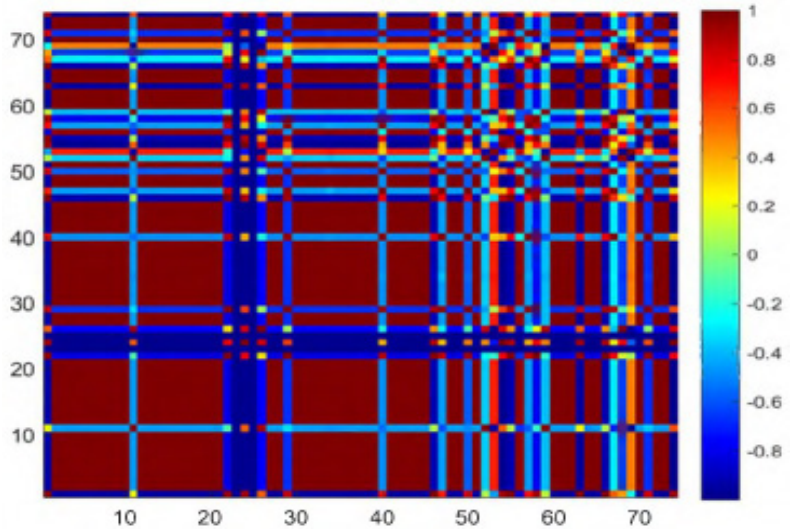

Figure 12. Matrix of mutual correlation of the impact of the stress indicator "Level of high-risk assets" on the integrated stabilizer of credit and investment activities of banks in attracting loans and deposits

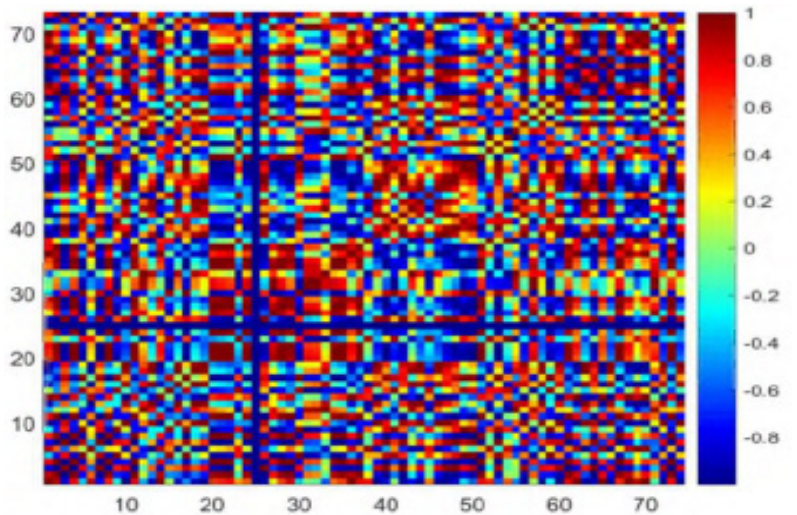

Figure 13. Matrix of mutual correlation of the impact of the stress indicator "Liquidity ratio" on the integrated stabilizer of credit and investment activities of banks in attracting loans and deposits 


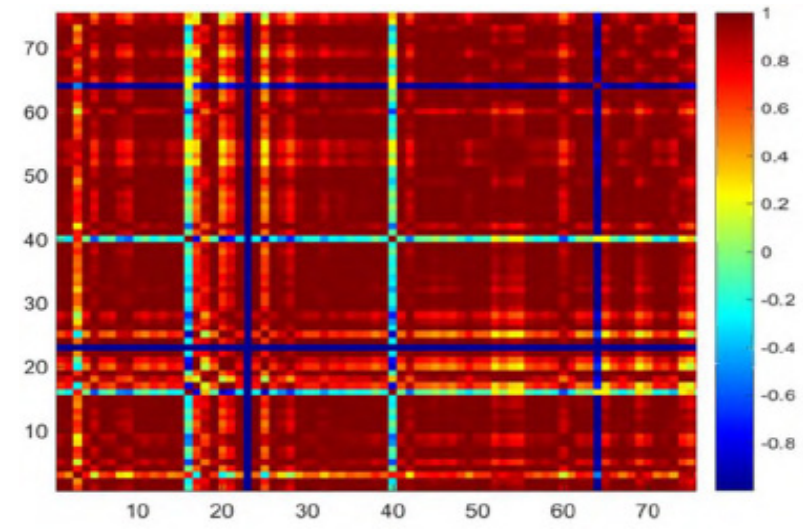

Figure 14. Matrix of mutual correlation of the impact of the stress indicator "Investment rate collateral" on the integrated stabilizer of credit and investment activities of banks in attracting loans and deposits

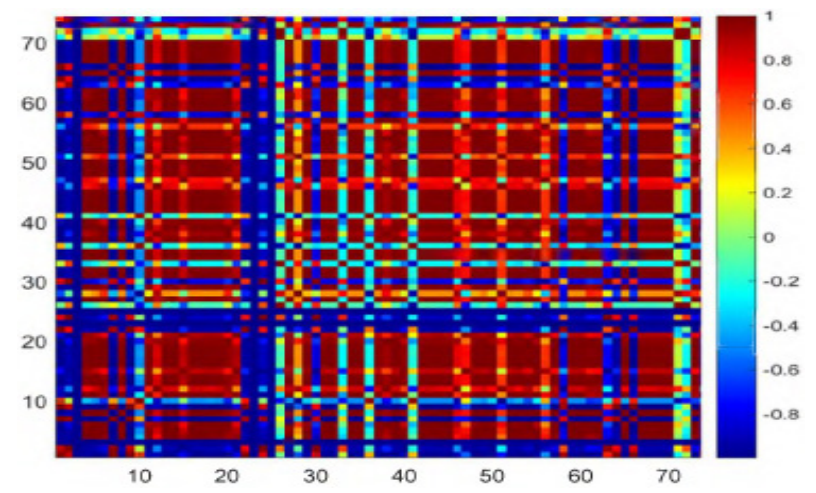

Figure 15. Matrix of mutual correlation of the impact of the stress indicator "Investment activity" on the integrated stabilizer of credit and investment activities of banks in attracting loans and deposits

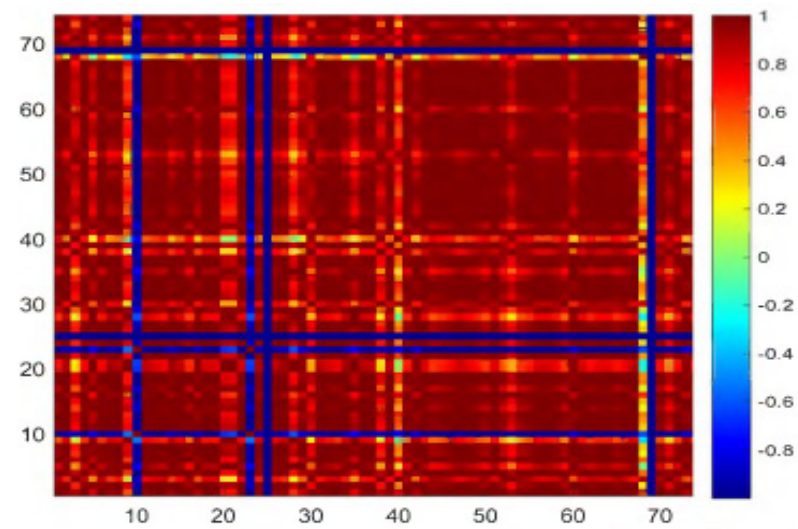

Figure 16. Matrix of mutual correlation of the impact of the stress indicator "Use of credit resources" on the integrated stabilizer of credit and investment activities of banks in attracting loans and deposits

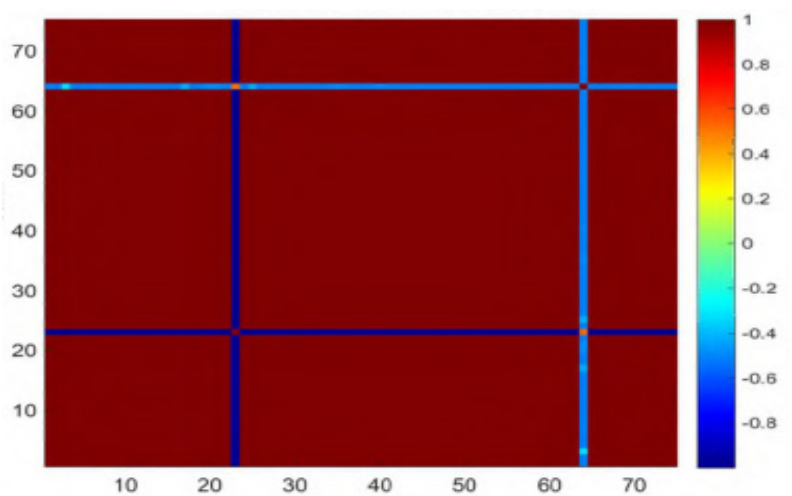

Figure 17. Matrix of mutual correlation of the impact of the stress indicator "Securing liabilities" on the integrated stabilizer of credit and investment activities of banks in attracting loans and deposits

Thus, in Figure 8, matrix of cross-correlations of the impact of the stress indicator "Risk protection" indicates that the maximum number of values (3640) is close to +0.1 ; increases in the distribution density are attributed to the range -1.0 to -0.9 , as well as the range from 0.6 to 0.7 are the values above two banks - CREDOBANK and Credit Optima Bank. The similarity of the dynamics of the level of total credit activity, mostly more than 0.6 is observed from 20-25 banks. In addition, there are several banks within which the dynamics of the level of return on assets is very similar, but between them the dynamics of the level of total lending activity (Figure 9) differs significantly, approaching the opposite. There is a lack of connection between the refinancing ratio and the integrated stabilizer of credit and investment activities of banks in the interbank market with loans and deposits (Figure 11).

At the same time, the distribution of the values of the matrix of mutual correlations of the impact of the stress indicator "Level of high-risk assets" on the integrated stabilizer (Figure 12) revealed that for a predominant group of banks, the correlation coefficient is close to +1.0 and the group of banks with correlation coefficient is less than -0.5 . The impact of the stress indicator "Liquidity ratio" (Figure 13) is similar in value to the level of return on assets and total lending activity. The interdependence of indicators on the level of investment security for all banks is similar, as evidenced by the values of the corresponding correlation coefficients - more than 0.8 (Figure 14), i.e., the density of the impact on the integrated stabilizer is high. Only the value of correlation coefficients for 6 banks - BANK PORTAL, 14 banks - PUMB, 20 banks - CREDIT OPTIMA BANK, 27 banks - CITYBANK significantly differs from the general trends. 
The distribution of the values of the matrix of mutual correlation of the impact of the stress indicator "Use of credit resources" on the integrated stabilizer of credit and investment activities of banks in the interbank market (Figure 16) is greater than +0.8 (2806 values of correlation coefficients), and ranges from +0.6 to +0.8 ( 288 values). That is, $83.67 \%$ banks have a close relationship with the integrated stabilizer of the level of investment security (use of own funds) to attract credit resources in the interbank market. This is atrributed to the crisis of the banking system of Ukraine which is caused by external threats of financial globalization. The high dependence of the integrated stabilizer of credit and investment activities of banks in the interbank market on the stress indicator "Securing liabilities" (Figure 17) indicates a similar trend in the functioning of banks in the distribution of values of the correlation matrix (1630 tested values are approaching to $1 ; 400$ values range from 0.8 to $0.9 ; 200$ values more than 0.5).

Thus, the results of modeling on the basis of covariance found that the most significant impact among stress indicators on the integrated stabilizer of credit and investment activities of banks in the interbank market in attracting loans and deposits are: risk protection, collateral, use of credit resources and level of investment collateral, as well as investment activity and the level of high-risk assets.Stress indicators - total credit activity, level of income assets and liquidity ratio are characterized by different effects on the integrated stabilizers of credit and investment activity of banks in the interbank market when attracting loans and deposits to serve customers;a stable inverse regression was found for the refinancing ratio (Figure 18).

Thus, the expected result of the interaction of stress indicators and their impact on the integrated stabilizer of credit and investment activities of banks in the interbank market in attracting loans and deposits allows developing regulators of money supply in the banking system as a whole, affecting the macroeconomic situation in the country, inflation rates, unemployment and gross domestic product. The results of their action are the implementation of basic and regulatory instruments to support macroeconomic, financial stability and economic growth of the state. The measures are aimed at using tools, including: ensuring the balance of the money supply; improving the parameters of the functioning of banking institutions in the credit and investment sector; unshadowing of settlement operations on loans and deposits in the monetary sector; counteracting the challenges of financial globalization in the activities of interbank market participants.

In countries such as the United States and Japan, two key financial services have been clearly separated segments- commercial and investment activities of banks. In the United States, these two segments were not united until 1933, but after the financial collapse of the 30 s of the twentieth century new legislation on banking was adopted, which is known as the Glass-Stigall law . It required a distinction between commercial and investment and founding activities of banks [40].

The reason for the adoption of this law was profound entrenched distrust in the concentration of economic and financial potential. This distrust reflected in the ban on merging the assets of financial and non-financial firms. If the law Glass-Stigol demanded the separation of investment and commercial activities, the other law - on bank holding companies - forbade non-banking companies to own banks [41]. Many Western European countries (Germany, France, Switzerland, Italy, Belgium) have universal banks, which can perform a wider range of financial transactions without restrictions.

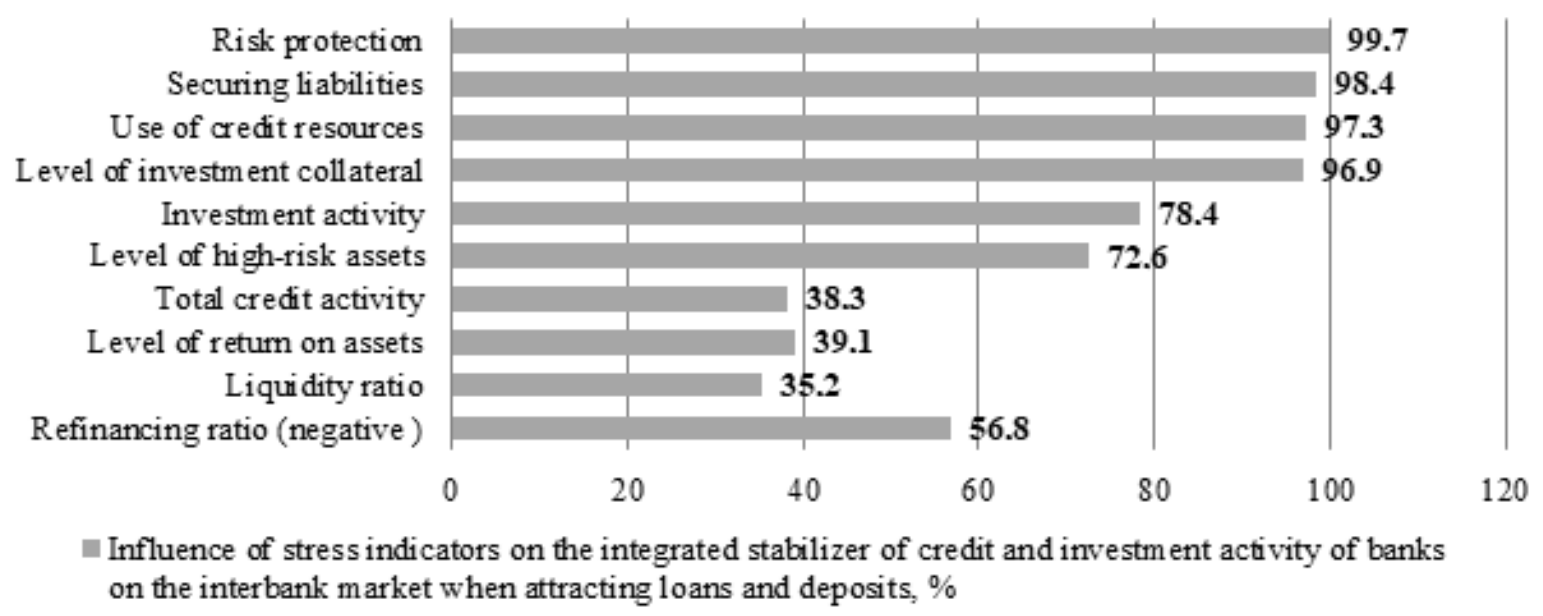

Figure 18. The relative impact of stress indicators on the integrated stabilizer of credit and investment activities of Ukrainian banks in the interbank market when attracting loans and deposits, \% 
According to the German law on banks, "any enterprise that performs one or more types of banking operations, namely the acceptance of deposits, the issuance of loans, leasing operations, payments and settlements with third parties, issuance of guarantees, trading in securities, safekeeping of valuables, etc." are included in credit institutions [42].

Thus, countries with highly developed economies have the legislative base and the mechanism of redistribution of the capital in which everyone financial institution performs certain functions. In Ukraine, the largest development of all financial structures received only banks, only the banking system is able to give credit or issue shares to raise money for investment. Most Ukrainian banks behave as universal banks, constantly diversifying their activities [43].

The world financial community (represented by the relevant associations) has been actively working in the field of standardization and unification of key aspects of credit and investment activities. In particular, in October 1999 at a meeting of the higher coordination body of the Confederations of Financial Analysts, the International Council of Investment Associations (ICI), which was attended by representatives of associations of Asia (ASAF), Europe (EFFAS), South America (IASSA), as well as the Association for Investment Management and Research (AIMR) , adopted decision to implement the Global Investment Standards in Europe (Global Investment Performance Standards, GIPS) [44-46].

Regarding the legal framework for investment activities of Western European banks, it should be divided into national legislation and European. The first main difference between EU legislation and the national law of EU member states is that, as a rule, the European Union has no laws, only directives that address specific legal issues and must be complied by national law. As the second difference, it is necessary to note that the EU rarely infuses the absolute level of legal standards [47, 48].

The problem of adapting Ukrainian banking legislation to European norms is greatly simplified due to the fact that many member states of the European Union also participate in the Basel Committee. This committee has developed a number of rules that are not mandatory recommendations and reflect the best practices of these countries. Thus, it can be argued that the recommendations of The Basel Committee are the best practice of the European Union.

\section{Conclusions}

As a result of the research, it was found that credit and investment bank activities are actually combined in a single loan and investment portfolio, so the banking institutions focus more on lending rather than investing and vice versa. After conducting a study of banks' loan and investment portfolios, it was founded that their structure and volume are heterogeneous. The largest share in the structure of the loan and investment portfolio is occupied by commercial loans, while the smallest are interbank loans.

For countries in the process of forming the banking infrastructure (including Ukraine), a method of a comprehensive assessment of stress indicators has been developed. It unifies threats and identifies risks in the bank's credit and innovation activities when attracting loans and deposits in the interbank market. The rationing method could help for ration the value of the coefficients that form a group of stress indicators and their weight value to calculate the integrated stabilizer of credit and investment activities of the bank on the interbank market.

Ensuring the balance of the money supply should be based on the effective use of risk minimization tools in the monetary policy of banking institutions by strengthening their positive impact on the money supply and their value. As a result, autors suggest to consider the mandatory reserve requirements one of the tools that banks can use in lending and investment activities as a factor in the formation of a moderate structural liquidity deficit of banks to control interest rates by the monetary regulator. To do this, the authors suggest it is necessary to improve the order of their formation and storage through expanding the criteria for differentiation of reserve requirements for absolute amounts of funds deposited in bank deposits, the target of loans provided by banks, the type of credit institutions, their size, and depending on the choice of priorities in time of active-passive operations; reduction of required reserves by the amount of long-term investment loans provided at the expense of independently formed resources, the amount of purchased government bonds and NBU certificates of deposit; the introduction of accrual and payment of interest on the amount of required reserves of banking institutions in order to improve the efficiency of customer service and depositors and the implementation of transparent settlement operations.

Instead, the main tool for regulating banks' lending and investment activities in the interbank market when attracting loans and deposits in Ukraine should be a key interest rate, the effective use of which to ensure the balance of money supply requires regulating the liquidity of banks (currently NBU certificates of deposit); unification of the discount rate and the rate on the main active-passive operations; narrowing the corridor of rates on oversight loans and oversight certificates of deposit; use of other operations to smooth the impact on interest rates of significant fluctuations in liquidity and promote the development of interbank markets. In order to effectively operate credit and investment activities of banks in the securities market as a factor of ensuring a balanced circulation of money in the banking system as a whole, it is necessary to introduce a set of measures . Primary and secondary government securities market and 
derivatives market should be developed, the level of liquidity of banks' operating activities should be increased by attracting private investors to the national banking system, providing them with simplified tax reporting on stock exchange transactions, facilitating the taxation of individuals under transactions with securities and derivative financial instruments; separation of clearing into a separate type of activity of banking institutions; market development of derivative financial instruments; liberalization of foreign exchange settlement operations when purchasing foreign securities; development of the settlement component of the money market infrastructure due to innovative financial technologies and their consolidation in the stock market systems.

\section{REFERENCES}

[1] G. Bekaert, C.R. Harvey. Capital flows and the behavior of emerging market equity returns, In: Capital inflows to emerging markets (pp. 159-94), National Bureau of Economic Research and University Press, Chicago, 2000.

[2] B.E. Hermalin, A.K. Rose. Risks to lenders and borrowers in international capital markets, NBER Working Papers, No. 6886, 173-193, 1999.

[3] R. Kiely. Globalization, post-Fordism and the contemporary context of development, International Sociology, Vol.13, No. 1, 27-43, 1998.

[4] I. Clark. Globalization and fragmentation. International relations in the twentieth century, Oxford University Press, New York, 1997.

[5] K. Kiljunen. Global governance, Institute of Development Studies, Helsinki, 1999.

[6] B. Lasarus. Charting globalization, Race \& Class, Vol. 2\3, No. 40, 38-49, 1998.

[7] L. Pauly, S. Reich. National structures and multinational corporate behavior: Enduring differences in the age of globalization, International Organization, Vol. 51, No. 1, 141-154, 1997.

[8] E. Perrot. Penser la mondialisation, Recherches de Science Religieuse, Vol. 86, No. 1, 121-133, 1998.

[9] R. Robertson, H. Knondker. Discourses of globalization: Preliminary considerations, International Sociology, Vol. 13, No. 1, 72-92, 1999.

[10] R.M. Stulz. Globalization of equity markets and the cost of capital, NBER Working Papers, No. 7021, 59-73, 1999.

[11] E.D. Dolan, K.D. Kempbell, R.D. Kempbell. Money, banking and monetary policy, Orchestra, Saint-Petersburg, 1994.

[12] P.R. Krugman, M. Obstfeld. International economics: Theory and policy, HarperCollins, New York, 1991.

[13] D.H. Lukianenko. Strategies for economic development in the context of globalization, Kyiv National Economic
University, Kyiv, 2001.

[14] S.V. Onyshko, T.H. Venhurenko, Yu.Yu. Verheliuk. Regulatory potential of the market in conditions of global challenges, Publishing House of the National University of the State Tax Service of Ukraine, Irpen, 2016.

[15] V.O. Onyshchenko, S.B. Manzhos. Regulation of foreign capital in the banking system: foreign experience and its implementation in Ukraine, Bulletin of the National Bank of Ukraine, No. 11, 16-21, 2013.

[16] C. Borio, Ph. Lowe. Asset prices, financial and monetary stability: exploring the nexus, BIS Working Papers, Vol. 114, Online available from: https://www.bis.org/publ/work 114.pdf, 2002.

[17] C. Borio, M. Drehmann. Towards an operational framework for financial stability: "fuzzy" measurement and its consequences, BIS Working Papers, Vol. 284, Online available from: http://www.bis.org/publ/work284.pdf, 2009.

[18] I. Chmutova, V. Biliaieva. Indicators of financial stability of the Ukrainian banking system, International Journal of Managerial Studies and Research, Vol. 3, No. 7, 95-103, 2015

[19] A.B. Kondrashykhin. Investment risks of the Ukrainian securities market, Banking: Scientific and Practical, No. 2, 62-71, 2003.

[20] V.V. Kornieiev, S. Kulpinskyi. Overcoming the deficit of investment resources with the help of the development bank's tools, Finance of Ukraine, No. 5, 82-96, 2016.

[21] V.V. Kovalenko. Strategic management of financial stability of the banking system, Ukrainian Academy of Banking of the National Bank of Ukraine, Kyiv, 2010.

[22] O.I. Lavrushin. Role of credits and modernization of banks' activity in the sphere of crediting, KnoRus, Moscow, 2012.

[23] R.L. Miller, D.D. Van-Huz. Modern money and banking, INFRA-M. Moscow, 2000.

[24] Dzh.F Sinki. Financial management in a commercial bank and in the financial services industry, Alpina Business Books, Moscow, 2007.

[25] Dzh.F. Sinki, R. Levita, B.S. Pinsker. Financial management in commercial banks, Catallaxy, Moscow, 1994.

[26] V. Mishchenko, V. Krylova, M. Nikonova. Restructuring of loans in a crisis: world experience and applications in Ukraine, Bulletin of the NBU, Vol. 5, 12-17, 2009.

[27] V.A. Khudaverdieva. Strategy for attracting foreign investment into the economy of Ukraine, Finance of Ukraine, Vol. 6, 62-69, 2010.

[28] Official site of the National Bank of Ukraine. Online available from: www.bank.gov.ua.

[29] L.L. Klyoba, Improving the management of banking investment activities, Bulletin of the NBU, No 5, 51-53, 2011.

[30] A.A. Peresada, T.V. Mayorova. Management of bank investments: Monograph, KNEU, Kyiv, 2005.

[31] A.E Kulakov. Management of assets and liabilities of the 
bank, Finance and Credit, Vol. 17, 2-16, 2002.

[32] Yu.B. Rubin, V.I. Soldatkin. Investment and financial portfolio, SOMINTEK, Moscow, 1993.

[33] S.A. Vavilov. Method for determining one integral characteristic for volatilities in the problem of investment portfolio management, Bulletin of Saint-Petersburg University, Vol. 1, 115-124, 2005.

[34] I.Ch. Angela, Kim-K. Raymond, L. Lin. An analysis of money laundering and terrorism financing typologies, Journal of Money Laundering Control, Vol. 15, 85-111, 2011.

[35] M. J. Flannery. Debt maturity and the deadweight cost of leverage: Optimal financing banking firms, American Economic Review, Vol. 84, No. 2, 320-331, 1994.

[36] D.W. Diamond, R.G. Rajan. Liquidity risk, liquidity creation, and financial fragility: A theory of banking, Journal of Political Economy, No. 109, 287-327, 2001.

[37] Basel Committee on Banking Supervision, A global regulatory framework for more resilient banks and banking systems, Basel committee on banking supervision, Online available from: http://www.bis.org/publ/bcbs189.pdf, 2011.

[38] Financial Statements of the Depository Corporations' Sector and the Second Financial Corporation's Sector, Online available from: https://bank.gov.ua/ua/statistic/sect or-financial/data-sector-financial\#4fsi, 2019

[39] International Monetary Fund, Publication Services, Financial stability indicators, Compilation guide, Online available from: https://bank.gov.ua/ua/stability/about, 2007.
[40] M.O. Burmaka, S.M. Antonov. The main directions of improving the regulatory framework market of Ukraine, Securities of Ukraine, Vol. 540, No.48, 13-28, 2008.

[41] V. Mishchenko. Features of post-crisis reform of the financial sector of Ukraine, Finance of Ukraine, Vol. 10, 3-11, 2010.

[42] Y. Derevko. Investment banks: influence on the formation of a mixed model of the securities market securities in Ukraine, Banking, Vol. 1, 90-98, 2008.

[43] V.V. Kozyuk. Credit expansion in the system of macrofinancial imbalances, Finance of Ukraine, Vol. 1, 54-61, 2010.

[44] V.M. Kossak, V.N. Denisov, Legal regulation of foreign investments, Ukrainian Center for Legal Studies, Kyiv, 2009.

[45] J.S. Sinaga, I. Muda, A.S. Silalahi. The effect of BI rate, exchange rate, inflation and third party fund (DPK) on credit distribution and its impact on non performing loan (NPL) on XYZ commercial segment bank, Universal Journal of Accounting and Finance, Vol. 8, No. 3, 55-64, 2020. DOI: $10.13189 /$ ujaf.2020.080301

[46] S.K. Dey, D. Sharma. Nexus between corporate governance and financial performance: corroboration from Indian banks, Universal Journal of Accounting and Finance, Vol. 8, No. 4, 140-147, 2020. DOI: 10.13189/ujaf.2020.080406

[47] S.V. Chebanov. International regulation of foreign direct investment: and problems, MEiMO, Vol. 12, 21-32, 2009.

[48] R.B. Shyshka, Investment law of Ukraine, Espada, 2007. 